\title{
WestVirginiaUniversity
}

THE RESEARCH REPOSITORY @ WVU

Graduate Theses, Dissertations, and Problem Reports

2011

\section{Effect of service sire on late embryonic and fetal loss in sheep}

Tammy L. Holler

West Virginia University

Follow this and additional works at: https://researchrepository.wvu.edu/etd

\section{Recommended Citation}

Holler, Tammy L., "Effect of service sire on late embryonic and fetal loss in sheep" (2011). Graduate Theses, Dissertations, and Problem Reports. 3280.

https://researchrepository.wvu.edu/etd/3280

This Thesis is protected by copyright and/or related rights. It has been brought to you by the The Research Repository @ WVU with permission from the rights-holder(s). You are free to use this Thesis in any way that is permitted by the copyright and related rights legislation that applies to your use. For other uses you must obtain permission from the rights-holder(s) directly, unless additional rights are indicated by a Creative Commons license in the record and/ or on the work itself. This Thesis has been accepted for inclusion in WVU Graduate Theses, Dissertations, and Problem Reports collection by an authorized administrator of The Research Repository @ WVU. For more information, please contact researchrepository@mail.wvu.edu. 
Tammy L. Holler

Thesis submitted to the

Davis College of Agriculture, Natural Resources and Design

at West Virginia University

in partial fulfillment of the requirements

for the degree of

Master of Science

in

Reproductive Physiology

E. Keith Inskeep, Ph.D. Chair

Robert A. Dailey, Ph.D.

P. Brett Kenney, Ph.D.

Department of Animal and Nutritional Sciences

Morgantown, West Virginia

2011

Keywords: Service Sire, Sire, Sheep, Loss, Ultrasonography, Ultrasound, Embryo, Fetal, Ram, Ewe, Late Embryonic, and Ovine 


\title{
ABSTRACT \\ EFFECT OF SERVICE SIRE ON LATE EMBRYONIC AND FETAL LOSS IN SHEEP
}

\author{
Tammy L. Holler
}

Very few authors have studied the effect of the sire on the outcome of pregnancy in sheep beyond differentiation, development, spermatogenesis, fertilization and early embryo survival. A major limitation in direct selection for increased sire competence is that males need to be selected mainly on the performance of their female relatives and females do not express lambing traits until at least one or two years of age. This selection process can be accelerated by studying prenatal survival ability of individual ram's progeny.

The objective of the present study was to identify occurrence of late embryonic and fetal mortality in relation to individual sires. The data set included 980 ewes on 10 farms; each each ewe pregnant to one of 67 rams of 12 breeds. Number of embryos or fetuses was determined by transrectal or transabdominal ultrasonography. Records of lambs born showed that potential litter size was underestimated in at least 166 of the ewes. Factors investigated for effects on numbers of lambs born were number of embryos at diagnosis (single or multiple), individual ram, breed of ram, month ewe was bred, breed of the ewe, age of the ewe, embryo type (purebred or crossbred), farm and interactions among these factors. The GLM procedure of SAS was used to examine the main effects and interactions of these factors on the pregnancy outcome.

Individual rams that ewes were bred to had a significant effect on the number of lambs born from the pregnancy. Individual rams sired from 0.70 lambs to 2.45 lambs born per pregnant ewe. In addition, litter size varied with the interaction of breed-type of ram and number of diagnosed embryos. Ewes diagnosed with twins were more often underestimated due to an unusually high number of triplet and quadruplet births. The number of lambs born increased linearly with the age of the ewe. The number of lambs born varied significantly $(<0.05)$ with farm as well as with the farm by number of diagnosed embryos interaction.

Losses of embryos and fetuses sired by hair-type rams (42\%) or black-faced rams $(30 \%)$ were greater than for white-faced rams $(20 \%)$ or dairy- type rams $(21 \%)$. Fewer partial losses were observed among embryos and fetuses sired by white-faced rams, but complete losses were greater for the hair-type and white-faced rams. Hair-type ewes (46\%) lost significantly more documented embryos or fetuses from the time of examination to birth than black-faced (27\%), white-faced (20\%), or dairy-type (25\%) ewes. Surprisingly, purebred embryos had fewer documented deaths than crossbred embryos. Losses varied with farm and the farm by number of diagnosed embryos interaction $(\mathrm{P}<0.001)$, reflecting both expected flock differences and the variation in breed-type composition of the flocks.

In conclusion, the sire influenced the conceptus's ability to develop to term. Although, much of the paternal role is still a mystery, careful ram selection based upon previous records of pregnancy losses in ewes they were bred to may decrease embryonic and fetal wastage by improving conceptus competence genetically. The individual sire's influence on the conceptus needs to be investigated further to determine repeatability and heritability of survival or loss and to better understand the mechanisms controlling the paternal factors influencing embryonic and fetal wastage in sheep. 
TABLE OF CONTENTS

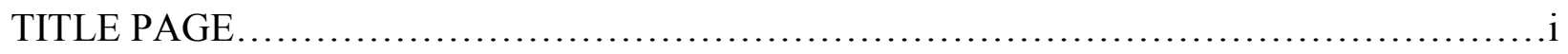

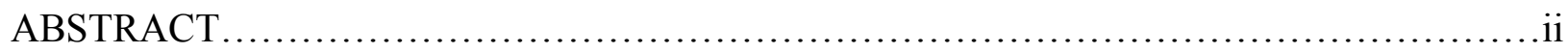

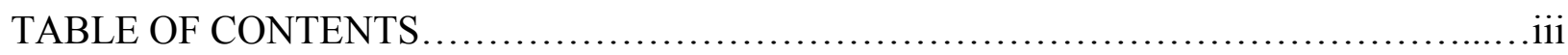

LIST OF TABLES...............................................................

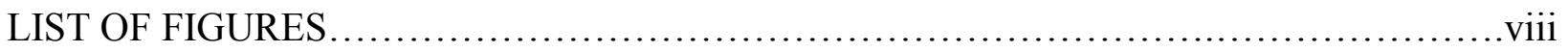

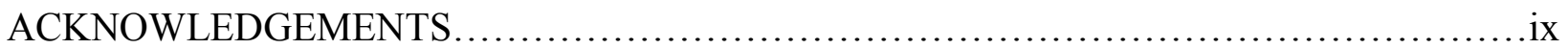

REVIEW OF LITERATURE......................................................

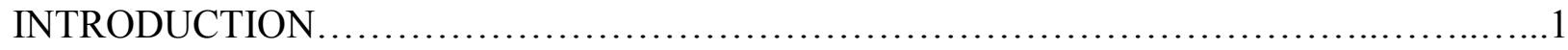

Oocyte maturation and ovulation...........................................

Luteolytic mechanism....................................................

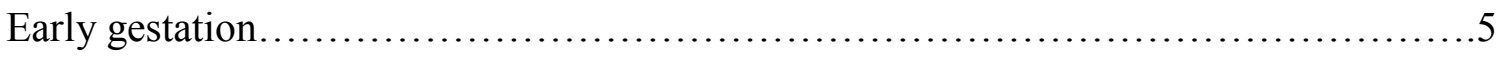

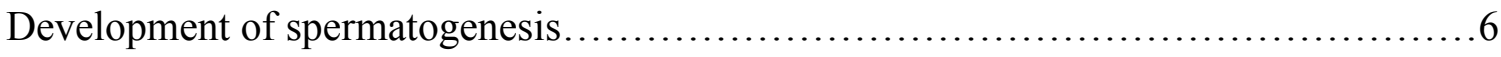

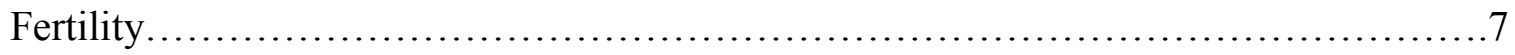

Fertilization rates.....................................................

Embryonic development pre-implantation....................................8

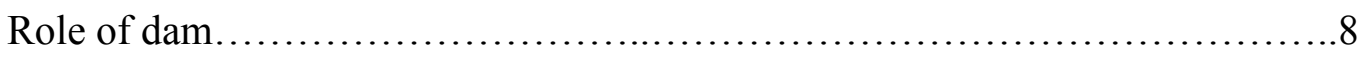

Role of embryo................................................... 9

Placental development................................................... 10

Factors associated with pregnancy losses................................. 11

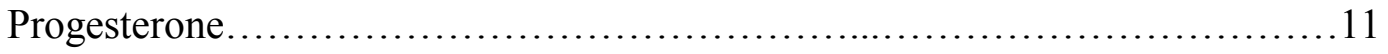

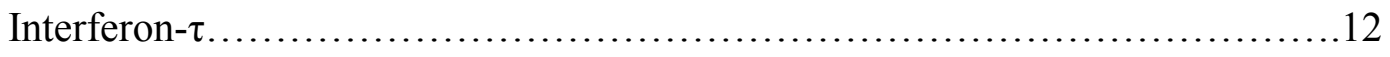

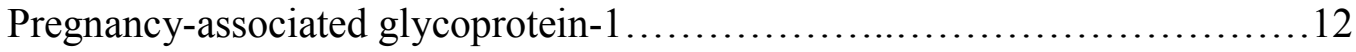




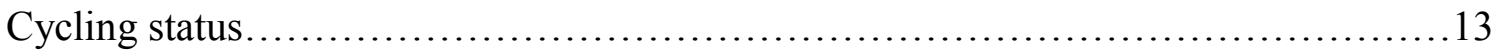

Oocyte quality and persistent follicles...................................13

Duration of proestrus and subsequent luteal phase...........................14

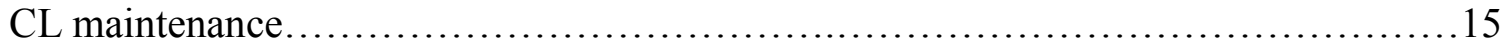

Nutritional stress and body condition......................................... 15

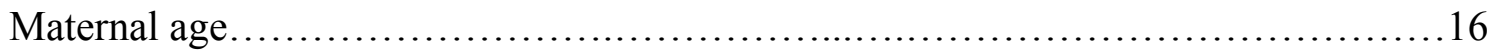

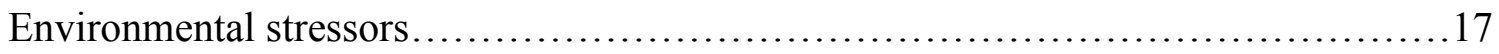

Management.............................................................

Heat Stress.................................................................

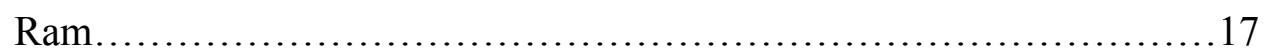

Ewe..............................................................

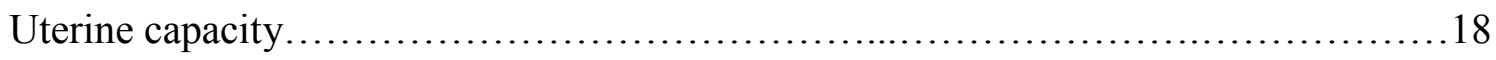

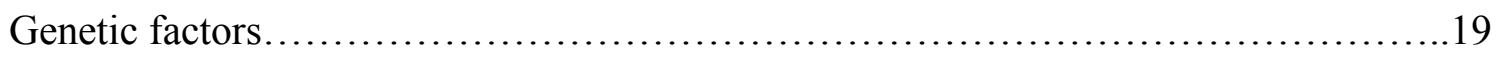

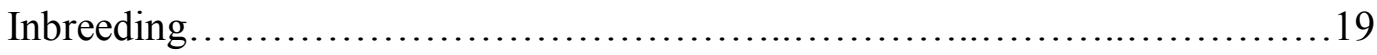

Chromosomal defects..................................................... 19

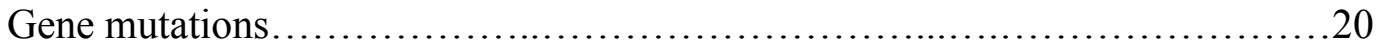

Breed differences....................................................................20

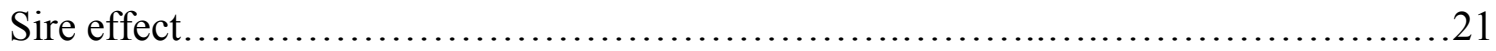

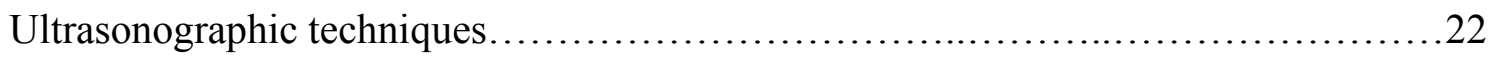

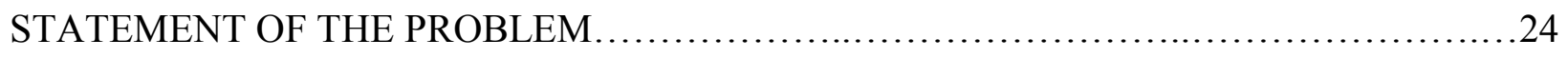

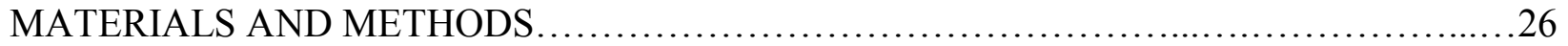

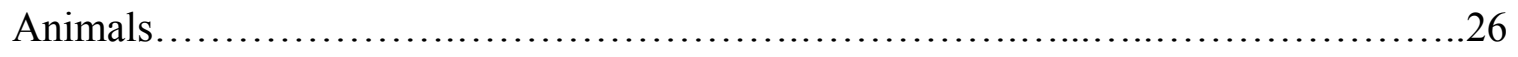

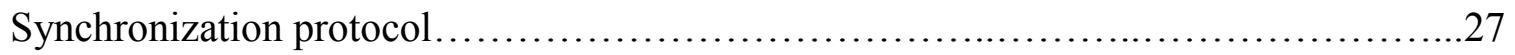


Pregnancy determination.

Factors involved in embryonic and fetal mortality .......................28

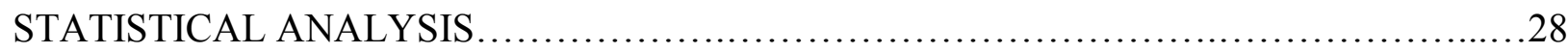

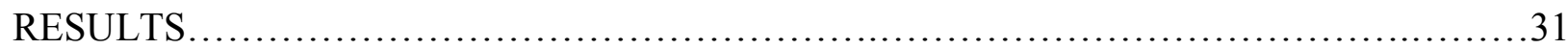

Effect of individual rams (service sire) on the number of lambs born.................. 31

Effect of breed-type of ram on the number of lambs born........................... 34

Effect of breed-type of ewe on the number of lambs born.......................... 35

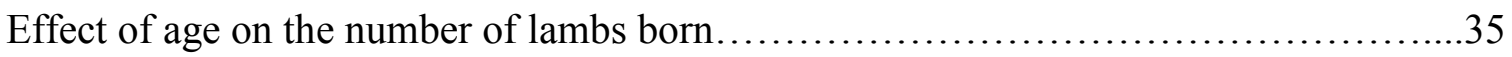

Effect of farm on the number of lambs born.....................................

Effect of season bred on the number of lambs born................................

Factors affecting losses in ewes in which diagnosis was not known to have

underestimated number of potential offspring.................................. 37

Effect of individual rams on the number of documented embryonic/fetal losses........37

Effect of breed-type on the number of documented embryonic/fetal losses.............37

Effect of ewe age on the number of documented embryonic/fetal losses................39

Effect of embryo breed-type on the number of documented embryonic/fetal losses.......39

Effect of farm on the number of documented embryonic/fetal losses.................40

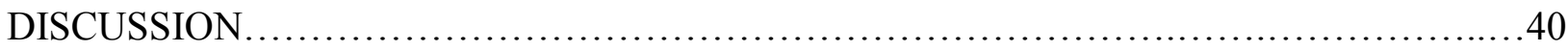

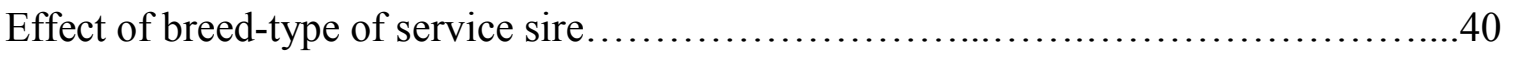

Relationships to breed-type and age of dam................................... 41

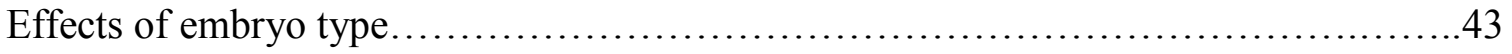

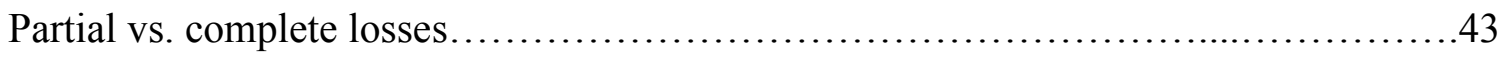

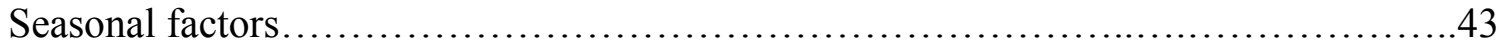


Accuracy of counts of embryos or fetuses...................................44

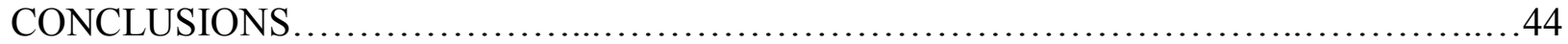

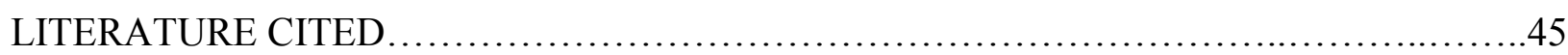

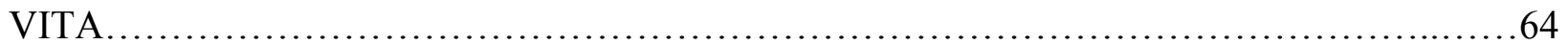


Table 1. Characterization of the data collected by farm............................29

Table 2. Analysis of variance for effects of ram (service sire), number of diagnosed embryos and their interaction on number of lambs born.......................30

Table 3. Median day of gestation ewe was examined, and number of ewes and percent of ewes that had more embryos or fetuses than documented per farm................31

Table 4. LS mean's of documented embryonic/fetal losses within individual farms as percentages of the total numbers of embryos or fetuses diagnosed by ultrasonography...................................................

Table 5. Percentages of documented embryonic/fetal loss for individual sires.............38 


\section{LIST OF FIGURES}

Figure 1. USDA-NASS statistical trend of the number of lambs born in the United States

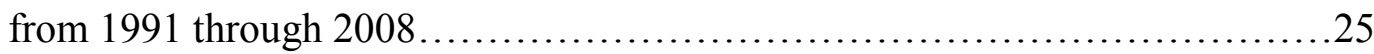

Figure 2. Distribution of rams in relation to number of lambs born......................34

Figure 3. LS mean of the number of lambs born in relation to the age of the ewe...........35

Figure 4. The estimated number of lambs per ewe and the actual number of lambs born per

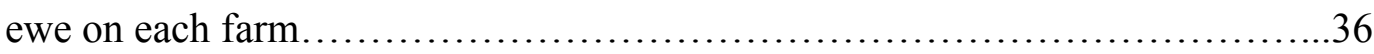

Figure 5. LS means embryonic or fetal losses in relation to ewe age......................39 


\section{ACKNOWLEDGEMENTS}

Foremost I give God the credit for making this possible by opening doors that I didn't know existed and placing the most extraordinary people in my life. Who we become as adults is set in motion at a very early age by the families we form through life's journey.

"When one door closes another door opens; but we so often look so long and so regretfully upon the closed door, that we do not see the ones which open for us". - Alexander Graham Bell

I would like to thank my Christian family that not only speak the words of God, but live every day of their lives for God. A very special thank you goes to my kindergarten teacher, Irene Hixon and her late husband Rev. Gail Hixon, also Wilma Friend and the late Hester Lewis, my long time Sunday school teachers, who inspired me to always do my best regardless of the obstacles, because God has a purpose for all things that happen in our lives.

"Perfection is not attainable, but if we chase perfection we can catch excellence". - Vince Lombardi, 1913-1970, American Football Coach

"Science has proof without any certainty. Creationists have certainty without any proof". Ashley Montague

My academic family has encouraged me throughout the years. Carolyn Deniker, the Biology professor at Garrett College, showed me I could achieve my most loved aspirations 
(creationism and science) without compromising the other. Willie Lantz has been a staunch advisor, educator, supervisor and friend. I would not be where I am today without the world's best mentor, Dr. E. K. Inskeep, who has been extremely patient with me. I consider studying under Dr. Inskeep a dream come true, he has endured all my questions and kept my grad work in perspective. I would also like to thank Dr. Robert Dailey for all the long hours of statistic work he helped me with and keeping the whole process fun and laughable. Dr. Bret Kenney has inspired me to strive to achieve the unachievable and conquer the unconquerable. Also, I appreciate the collaboration of WVU Reymann Memorial Farm, WVU's Morgantown teaching flock, Snowy Creek Dorsets (Mark Teets), Fulk Farm (Ron and Deb Fulk), the University of Wisconsin-Madison (Dr. David Thomas), Cornell University (Dr. Michael Thorney), Ohio State University (Drs. Joy Pate and Daniel Poole), and the University of Maryland Eastern Shore (Dr. Niki Whitley) for providing animals for my research. I will always be grateful to WVU's many faculty, staff, and fellow grad students who have helped with my research and/or played a part in my life to make me a better scientist and more knowledgeable person.

"Destiny is no matter of chance. It is a matter of choice. It is not a thing to be waited for, it is a thing to be achieved". - William Jennings Bryan, 1860-1925

Last but not least, I would like to thank my family, especially my mother (Neomia Holler) who has sacrificed her whole life for me, by taking the time to home school me she prepared me to be very studious and taught me to always set high goals for myself. Also, I am very grateful for all the support, encouragement, prayers, and etc. that my mother, sister 
(Kimberly Holler), Uncle Ervin Shreve and Aunts Bonnie Shreve and Jean Noel-Trickett have given me during my graduate work years.

"What you get by achieving your goals is not as important as what you become by achieving your goals" -. Zig Ziglar

Ten years ago, I would never have imagined studying reproductive physiology, but here I am just where God would have me. Not long ago it was embarrassing to explain the differences between a male and female rabbit, now nothing is more enjoyable than finding a fellow science enthusiast or someone desperately looking for answers to a reproductive problem. I don't know what is in store for me in the next decade, but I'm sure the last ten years of training has prepared me for my future.

"Progress lies not in enhancing what is, but in advancing toward what will be". - Kahlil

Gibran

"To raise new questions, new possibilities, to regard old problems from a new angle, require creative imagination and marks real advances in science". - Albert Einstein 


\section{REVIEW OF LITERATURE}

\section{INTRODUCTION}

The frequent occurrences of embryonic and fetal mortality in sheep are imposing increased financial hardships on an already economically challenged industry. Embryonic and fetal losses in sheep were first recognized by William Henning in the 1930's. At that time, Henning was unable to separate embryonic mortality from fertilization failure (Henning, 1939). Embryonic development begins at conception and continues for the first $45 \mathrm{~d}$ of gestation, followed by fetal development from gestation day 46 to term $(\sim 146 \mathrm{~d})$ in the ewe.

Embryonic development is initiated by syngamy of the male and female pronuclei. The fate of the embryo is uncertain at this stage. To complete development, the embryo must progress through a series of preprogrammed developmental steps that transform it from an undifferentiated one-cell organism to a functional, near replica of its parents. The probability of successful development is already pre-determined at syngamy, at least in part, by virtue of the genetic and non-genetic inheritance that the embryo receives from the gametes from which it was formed (Palermo et al., 1997). Subsequent errors in the execution of its developmental program can lead to embryonic or fetal mortality.

Three sources characterize pregnancy failure after breeding: fertilization failure, embryonic loss, and fetal loss. When the interestrous or interovulatory intervals are extended in bred animals, it usually indicates that embryonic loss occurred around the time the embryo normally signals the need for corpus luteum (CL) maintenance, commonly known as maternal recognition of pregnancy (Van Cleeff et al., 1991; Humblot, 2001). Experiments with frequent measurements of progesterone concentration in blood indicate that embryonic death during the 
time of CL maintenance delayed luteolysis and extended interestrous interval (Humblot, 2001). When embryonic death precedes luteolysis, luteal regression is delayed by at least 3 days after the end of pregnancy (Roberts et al., 1990; Kastelic et al., 1991). However, when luteolysis precedes conceptus death, and probably causes embryonic death, returns to estrus are dependent upon the stage of follicular development. Humblot (2001) suggested that luteolysis and return to estrus prior to day 24 in the cow might be linked with fertilization failure or early embryonic death; however, if the CL is maintained and returns to estrus are delayed beyond day 24 , it could point to embryonic losses occurring after day 16 of gestation in cattle. Thus, pregnancy losses prior to day 24 indicate early embryonic losses, and those between days 24 and 45 indicate late embryonic losses. Pregnancy losses detected after day 45 characterize fetal losses.

Oocyte Maturation and Ovulation. Sheep are spontaneous ovulators characterized by recurring estrous cycles with an average length of 17 days and regulated by the hypothalamic / pituitary / ovarian axis. Sheep begin to cycle as day length decreases in late summer or early fall; therefore, the term, "short-day breeder", is used to describe their cyclic estrous pattern. The estrous cycle can be divided into four stages: (1) proestrus, (2) estrus, (3) metestrus, and (4) diestrus. Folliclestimulating hormone (FSH) from the anterior pituitary stimulates growth of Graafian follicles. As proestrus draws near, FSH secretion and blood concentrations decrease due to frequent pulses of gonadotropin releasing hormone $(\mathrm{GnRH})$ that generate frequent pulses of luteinizing hormone $(\mathrm{LH})$, which stimulate secretion of estrogen $\left(\mathrm{E}_{2}\right)$. Estrus lasts about $30 \mathrm{~h}$, and as it approaches, peripheral blood concentrations of $\mathrm{E}_{2}$ are high and concentrations of progesterone are very low. Just before onset of estrus, the hypothalamus secretes more frequent pulses of GnRH (reviewed by Knights et al., 2001a, 2001b, 2003). 
Shortly after onset of estrus, ovulation occurs in response to an $\mathrm{E}_{2}$-induced surge of LH from the anterior pituitary. In response to the $\mathrm{LH}$ surge, $\mathrm{E}_{2}$ declines and $\mathrm{LH}$ stimulates a process termed luteinization, that involves differentiation and reorganization of thecal and granulosal cells from the ruptured follicles into small and large luteal cells and culminates in formation of CL (Schrick et al., 1993; Kusina et al., 1995). During diestrus, functional CL secrete progesterone that inhibits estrous behavior and formation of ovulatory follicles by attenuating release of LH (Al-Matubsi et al., 2001; Sheep, 2003). The concentration of $E_{2}$ in serum remains low while progesterone is high. Diestrus lasts until the onset of luteolysis, which is the functional and structural regression of the CL (McCracken et al. 1971, 1999). Then during proestrus, progesterone concentrations decline and $\mathrm{E}_{2}$ concentrations increase, as one or more ovulatory Graafian follicles become dominant on the ovary and the cycle is completed.

Luteolytic Mechanism. In sheep, the estrous cycle and luteolysis are dependent on the uterus because the endocrine luteolysin, prostaglandin $\mathrm{F}_{2} \alpha\left(\mathrm{PGF}_{2} \alpha\right)$, from the uterus initiates functional and structural regression of the CL (McCracken et al., 1999; O'Callaghan et al., 2000). Thus, the decrease in progesterone allows the estrous cycle to begin again (Jackson et al., 2000). During the estrous cycle, the ovine endometrium releases luteolytic pulses of prostaglandin from endometrial luminal epithelia (Hooper et al., 1986; Wathes and Lamming, 1995; Charpigny et al., 1997; Gray et al., 2000). It has been believed that this occurs in response to oxytocin that is synthesized and secreted by large luteal cells (Robert et al., 1976; Wathes and Hamon, 1993) as well as from the posterior pituitary (Hooper et al., 1986) and involves an increase in oxytocin receptors in the uterus. The uterine epithelia express PTGS2 (prostaglandin-endoperoxide synthase 2; prostaglandin $\mathrm{G} / \mathrm{H}$ synthase 2 or cyclooxygenase 2; alias COX-2), the rate limiting 
enzyme in prostaglandin synthesis (Charpigny et al., 1997a, 1997b), as well as oxytocin receptors (Wathes and Lamming, 1995). According to this concept, the endometrial luteolytic mechanism in ovine endometrial epithelia requires sequential effects of progesterone, $\mathrm{E}_{2}$, and oxytocin, acting through their respective receptors (McCracken et al., 1984; Spencer and Bazer, 1996, 2002).

In the ovine uterus, expression of the oxytocin receptor is regulated, primarily, by estrogen receptor alpha (ESR1) and progesterone receptor (McCracken et al., 1984; Wathes and Hamon, 1993; Spencer and Bazer, 1995; 1996). During estrus (Day 0 of the estrous cycle) and metestrus, $E_{2}$ released from ovulatory Graafian follicles stimulates expression of uterine ESR1, progesterone receptors, and oxytocin receptors in the endometrial luminal epithelia and uterine epithelia (Wathes and Hamon, 1993; Spencer and Bazer, 1995, Gray et al., 2000). During diestrus, increased circulating concentrations of progesterone act through epithelial progesterone receptors (McCracken et al., 1984). Activated progesterone receptors "block" expression of ESR1 and oxytocin receptors in the endometrial luminal epithelia and uterine epithelia between Days 3 and 11 of the estrous cycle (McCracken et al., 1984). Therefore, ESR1 and oxytocin receptor expression are not detected during most of diestrus. After days 11 to 12 of the estrous cycle the "progesterone block" is removed, because continuous exposure of the uterus to progesterone for 8 to 10 days down-regulates expression of progesterone receptors in endometrial luminal epithelia (Wathes and Hamon, 1993; Spencer et al., 1995), allowing rapid increases in ESR1 expression on Day 13 followed by oxytocin receptor expression on Day 14 in luminal epithelia and uterine epithelia (Hixon and Flint, 1987; Spencer et al., 1995a). On Days 14 to 16 of the estrous cycle, oxytocin secreted from the posterior pituitary and/or CL binds to the plasma membrane of endometrial epithelia and activates the protein kinase $\mathrm{C}(\mathrm{PKC})$ 
signaling pathway (Silvia and Raw, 1993) resulting in secretion of luteolytic $\mathrm{PGF}_{2} \alpha$ pulses from the endometrial luminal epithelia (Hooper et al., 1986; Wathes and Lamming, 1995). Pulses of luteolytic $\mathrm{PGF}_{2} \alpha$ over a 25-h period cause the CL to undergo functional and structural regression that allows the ewe to return to estrus, completing the 17-day estrous cycle. During the estrous cycle, progesterone plays a pivotal role in the initiation of increased endometrial $\mathrm{PGF}_{2} \alpha$ synthesis; progesterone increases phospholipid stores in luminal epithelia to maximal values on Days 14 and 15 of the estrous cycle (Boshier et al., 1987).

In a recent study by Niswender et al. (2007), oxytocin exerted a dose dependent effect on the $\mathrm{CL}$ that may play an intermediary role in the action of $\mathrm{PGF}_{2} \alpha$, promoting luteal regression (Murdoch and Van Kirk, 1998). In addition to progesterone receptor down regulation; oxytocin receptors were up-regulated as the luteal phase progressed, initiating a positive feedback loop within the CL. As reviewed by Goodman and Inskeep (2006), uterine platelet-activating factor and luteal oxytocin act in a synergistic manner that could account for the dramatic increase in secretion of $\mathrm{PGF}_{2} \alpha$ by the CL during the late luteal phase (McCracken et al., 1984). Oxytocin is released from large luteal cells and binds to oxytocin receptors on small luteal cells. Mankey (2009) demonstrated a linear and quadratic dose dependent effect of atosiban on circulating progesterone in the ewe. Atosiban is an oxytocin receptor antagonist that may also act as an oxytocin agonist, thus reducing concentrations of serum progesterone. The atosiban was delivered by implanted osmotic mini-pumps within the CL. Further research is needed to understand the mechanisms that regulate luteal $\mathrm{PGF}_{2} \alpha$ and oxytocin.

Early Gestation. Embryonic development is very complex as reviewed by Dixon (2007). The embryo enters the uterus on Day 4 after syngamy, at the morula stage of development, and then 
develops into a blastocyst on Day 6 (Guillomot et al., 1981; Guillomot, 1995; Senger, 2005). Between Days 8 and 9, the blastocyst sheds the zona pellucida by enzymatic lysis involving uterine and/or embryonic proteases (Guillomot et al., 1981; Guillomot, 1995; Senger, 2005). After Day 10, the blastocyst elongates into a tubular and then a filamentous conceptus (Wintenberger-Torres and Flechon, 1974; Senger, 2005). Between Days 16 and 22, the trophoblast begins to adhere firmly to the luminal epithelium by interdigitation between uterine epithelial microvilli and projections of the trophectoderm cells, and/or penetration into the uterine epithelia by papillae of the trophoblast (Boshier, 1969; Guillomot et al., 1981; Guillomot and Guay, 1982; Wooding et al., 1982). During this time, the trophoblastic giant cells migrate, appose, and fuse to the apical surface of the endometrial luminal epithelium to form syncytial plaques (Wimsatt, 1951; Wooding, 1984; Senger, 2005). Eventually, as a part of synepitheliochorial placentation in sheep, the syncytial plaques cover the caruncular surface and aid in formation of the placentomes, which are structures formed by fusion of placental cotyledons and endometrial caruncles (Wooding, 1992; Senger, 2005). Most early embryonic losses occur during placental development.

Development of Spermatogenesis. Initiation of spermatogenesis requires support from Leydig and Sertoli cells (Skinner, 1991; Senger, 2005). Differentiation of Leydig and Sertoli cells coincides with increased production of gonadotropins by the pituitary gland and production of testosterone by the Leydig cells (McCarthy et al., 1979). Spermatogenesis is a complex process in the testis, involving production of A- type spermatogonia and conversion of A-type spermatogonia into mature spermatozoa (Hochereau-de Reviers, 1976). Spermatogenesis starts with proliferation of A-spermatogonia (Hochereau-de Reviers, 1976; Senger, 2005). Cells 
undergo six mitotic divisions (3 type A, one intermediate and two B type spermatogonia) yielding 16 primary spermatocytes (Berndtson and Desjardins, 1974; Hochereau-de Reviers, 1976). Proliferation of A-spermatogonia is correlated with increased FSH secretion (Courot, 1967; Courot et al., 1979). Spermatocytes develop by 10 (Skinner et al., 1968a) or 12 (Crim and Geschwind, 1972a) weeks of age in ram lambs and development of spermatids is completed between 16 and 18 weeks of age (Skinner et al., 1968a).

The pituitary is essential for onset of spermatogenesis (Walton et a1., 1980). The onset of spermatogenesis is related to postnatal LH secretion, around 3 weeks of age (Wilson and Lapwood, 1979; Echternkamp and Lunstra, 1984). Inhibition of LH and FSH secretion inhibited the progress of spermatogenesis in ram lambs (Schanbacher, 1984). Testosterone is required for the final maturation of spermatids (Sharpe, 1990). The inhibition of testosterone production disrupts spermatogenesis in rams (Schanbacher, 1984). Immunization against testosterone or GnRH also affected the onset of spermatogenesis (Schanbacher, 1982b). Hormonal interrelationships between the hypothalamus-pituitary and testis are required for normal spermatogenesis (Desjardins, 1978; Desjardins, 1981; Schanbacher, 1982a). Many factors can cause normal spermatogenesis to cease, thereby disrupting normal reproductive function in the male.

Fertility. Various breeds of sheep express variable degrees of seasonality. Breeds that were developed in the subtropics or tropics are generally less seasonal than breeds developed in and around the British Isles (Arroyo et al., 2007). Seasonality traits are heritable (10\%); therefore, longer estrous seasons can be achieved by genetic selection (Al-Shorepy and Notter, 1997; Chemineau et al., 2008). 
In rams and bucks, spermatogenic activity and sexual behavior vary with season. Testicular size, plasma FSH, and testosterone concentrations as well as aggressive behavior reach their maximum between September and November (Lincoln, 1979; Ortavant et al., 1985; Delgadillo et al., 1992).

Fertilization Rates. Fertilization is believed to be an all-or-none phenomenon in respect to oocytes ovulated at a given estrus (Restall et al., 1976a, 1976b). In ewes, fertilization rates of 9095\%, or even higher, can be expected (Mitchell et al., 1999). Zygotes depend not only on maternal involvement but also on paternal contributions (Palermo et al., 1994, 1997). The maternal contribution depends largely on the ability of the oocytes to undergo maturation prior to fertilization. There is some evidence that fertilization rates may be compromised during the early (Hulet et al., 1956) and latter parts of the breeding season, perhaps as a consequence of suboptimal mating activity in some rams or adverse environmental and nutritional conditions that limit ram or ewe fertility (Mitchell et al., 1996).

\section{Embryonic Development Pre-Implantation}

A. Role of Dam. Conceptus survival and growth are dependent upon endometrial responses to pregnancy. During early pregnancy, the endometrium synthesizes and secretes, as well as selectively transports a variety of substances, collectively termed histotroph, into the uterine lumen (Amoroso, 1951; Bazer, 1975; Murray, 1993). Histotroph is complex and contains numerous binding and nutrient transport proteins, ions, mitogens, cytokines, lymphokines, glucose, enzymes, hormones, growth factors, protease inhibitors and many other substances (Bazer and First, 1983; Simmen and Simmen, 1990; Martal et al., 1997; Carson et al., 2000). 
Histotroph contributes to trophoblast growth regulation, conceptus attachment and implantation, and perhaps immunological protection of the fetus (Flèchon et al., 1986; Roberts and Bazer, 1988; Geisert et al., 1992; Lee et al., 1998). Endometrial gland histotrophs may play an important role in hematotrophic nutrition during mid- to late gestation (Wimsatt, 1950; Guillomot et al., 1981; Stewart et al., 2000).

B. Role of Embryo. The conceptus undergoes an extended period of growth and development prior to implantation (Guillomot, 1981). Implantation marks the beginning of the process of placentation. Implantation in sheep is not initiated until Day 15 (Day 0 syngamy); and it involves the trophectoderm coming into contact with discrete caruncular areas of the uterine epithelium and extension of villous interdigitations into the endometrial glands (Boshier, 1969; King et al., 1980; Guillomot et al., 1981; Spencer et al., 2004). Prior to this period, the conceptus is dependent upon secretions produced by the uterus. The embryo has some capacity to direct the maternal system to produce a local environment that serves the needs of the embryo. Uterine secretions must provide sufficient nutrients for the conceptus to simultaneously undergo major cellular restructuring, as well as production of biochemical signals for maternal recognition of pregnancy (Thatcher et al., 1995; Roberts et al., 1996). Interferon- $\tau$ (IFN- $\tau$ ) is the signal produced by the ruminant conceptus that acts in a paracrine manner on the maternal endometrium to elicit pregnancy recognition (Leung et al., 2000; Spencer et al., 1996, 2004). It has long been assumed that a portion of pregnancies fail because the embryo produces inadequate amounts of IFN- $\tau$ to block uterine $\mathrm{PGF}_{2} \alpha$ production or action and thereby continued maintenance of the CL fails (Thatcher et al., 1989; Roberts et al., 2003). 
There is considerable variation in the degree of trophoblast elongation between $\mathrm{d} 15$ and 17 of pregnancy when the embryo first secretes IFN- $\tau$ in anti-luteolytic concentrations (Leung et al., 2000). Interferon- $\tau$ secretion increases as size of the embryo increases (Leung et al., 2000). The dogma has been that IFN $\tau$ maintains the CL by inhibiting estrogen receptor (ER) and oxytocin receptor (OTR) gene expression, and therefore, endometrial production of luteolytic pulses of $\mathrm{PGF}_{2} \alpha$ (Thatcher et al., 1989; Spencer et al., 1995a, 1995b, 1999). Recently, Bott et al. (2008; 2009) determined that IFN $\tau$ was secreted into the uterine vein; therefore, it acted not only in an endocrine manner but also systemically in the CL; IFN $\tau$ induced ISG15 gene expression that helped maintain the CL. Interferon- $\tau$ affected the CL by suppressing PTGFR (antiluteolytic effect) and increasing PTGER3 (luteotrophic) mRNAs during maternal recognition of pregnancy in ewes (Antoniazzi et al., 2009).

Interferon- $\tau$ may also protect the conceptus from the maternal immune response and induce secretion of endometrial histotroph into the uterine lumen to aid in conceptus growth and development (Amoroso, 1951; Bazer, 1975). During the peri-implantation period of embryonic development, the trophoblast helps support rapid elongation, maternal recognition, and the absorption of histotroph as a nutrient source (Leung et al., 2000).

Placental Development. Most embryonic losses have been considered to occur at the time of placentome initiation, attachment and maternal pregnancy recognition (Cross, 2000, 2001). However, in cattle, Maurer and Chenault (1983) and Ayalon $(1978,1981)$ reported significant losses before day 8 . The ovine conceptus superficially attaches to the endometrium and ultimately obtains hematotrophic nutrition from placentomes. Placentomes are formed by interdigitation of the villi of a maternal caruncle and a placental cotyledon. Implantation is a 
highly coordinated process that involves apposition, attachment, and adhesion of the endometrial luminal epithelium and conceptus chorionic villi (trophectoderm) (Guillomot, 1995). Attachment of the conceptus trophectoderm and luminal epithelium is initiated on Day 14, followed by adhesion on Day 15, and attachment on Days 16 to 18 (Guillomot et al., 1981). Attachment involves interdigitation of the microvilli between the two epithelial layers. During cotyledonary placentation in sheep, trophoblastic giant binucleate cells begin to differentiate between Days 14 and 16 and then fuse apically with the endometrial luminal epithelium to form placentomes, thereby assimilating and replacing the endometrial luminal epithelium (Wimsatt, 1950; Wooding, 1984).

Placentomes are regulated temporally by non-adhesive and adhesive factors on the apical surface of the luminal epithelium (Burghardt et al., 1997, 2002; Lessey, 2002). Integrins are the dominant glycoproteins that regulate adhesion to endometrial luminal epithelium (Lessey, 1998; Carson et al., 2000; Johnson et al., 2001a). By mid-gestation, placental development is complete (Hutchenson et al., 1962; Rosenfeld et al., 1974).

Factors Associated with Pregnancy losses. Dixon (2007) completed an extensive literature review of the hormones associated with embryonic and fetal loss.

A. Progesterone. Progesterone, the hormone of pregnancy, plays an important role in the establishment and maintenance of a uterine environment that supports conceptus development (Ashworth et al. 1989; Diskin and Niswender, 1989). Endometrial gland secretions include growth factors, cytokines, and ions, these secretions are regulated predominantly by progesterone. Endometrial gland secretions are required for pre-implantation conceptus survival, 
elongation, and development (Spencer et al., 1999b; Gray et al., 2001; Dixon et al., 2007). Low progesterone portends loss, but the conceptus usually dies before luteal regression. Low concentrations of progesterone lead to excessive concentrations of other hormones that may cause embryonic death (Stronge et al., 2005; Diskin et al., 1989, 2006; Wurst, 2007).

$B$. Interferon- $\tau$. A proportion of pregnancies fail presumedly because the embryo produces inadequate amounts of interferon- $\tau(\mathrm{IFN}-\tau)$ to block uterine secretion or action of $\mathrm{PGF}_{2} \alpha$, thereby continued maintenance of the CL fails (Thatcher et al., 1989). Schrick et al. (1993) observed that $\mathrm{PGF}_{2} \alpha$ concentrations in uterine flushings of cows with short luteal phases were more than double those from cows with normal luteal phases during the early part of the cycle. Secretion of IFN- $\tau$ must increase as size of the embryo increases if the pregnancy is to be maintained (Leung et al., 2000). Compromised development of the embryo and underdevelopment of the trophectoderm are, therefore, considered responsible for premature luteolysis. Many embryonic losses are thought to be mediated by the inability of the embryo to suppress the luteolytic cascade (Thatcher et al., 1986; Roberts et al., 1992).

\section{Pregnancy-associated glycoprotein-1. Pregnancy-associated glycoprotein-1 (PAG-1)} concentrations in maternal blood are considered a marker of fetal/placental well being. Either low or high plasma concentrations of PAG-1 predicted a greater risk of conceptus mortality (Zarrouk et al., 1999a, 1999b; Humblot et al., 2001). In a study conducted by Lopez-Gatius et al. (2007) in dairy cows, early fetal loss could be predicted on d 35 of gestation. 


\section{Cycling Status}

A. Oocyte quality and persistent follicles. Higher fertilization failure and embryonic mortality were observed in cattle and sheep when estrus was synchronized, especially with low dosages of progesterone (Lunstra and Christenson, 1981; Ahmad et al., 1995; Inskeep, 1995; Santos et al., 2004; Wurst, 2007). Synchronization protocols that induced estrus after allowing the dominant follicle to continue to grow might compromise the oocyte ovulated from a persistent follicle (Lunstra and Christenson, 1981; Ahmad et al., 1995; Santos et al., 2004). Reduced conception rates on first service and embryonic and fetal death will result. In a study conducted by Viñoles et al. (2001), a 12-day intravaginal progesterone treatment increased age of the average follicle ovulated by two days, therefore possibly compromising oocyte competence. Johnson et al. (1992) found that low progesterone concentrations, from days 7 to 15 of the estrous cycle, influenced older follicles to ovulate and caused reduced conception in ewes. In contrast, Evans et al. (2001) found that persistent follicles did not influence fertilization rate, embryo quality, or fetal survival to term.

When beef cows were subjected to the Co-Synch timed AI protocol (day $0 \mathrm{GnRH}$, day 7 $\mathrm{PGF}_{2} \alpha$, day $9 \mathrm{GnRH}$ and timed $\mathrm{AI}$ ) or were inseminated upon detection of spontaneous estrus (Perry et al., 2003a, 2003b), embryonic/fetal survival was reduced. Reduced survivability occurred when follicles $<11 \mathrm{~mm}$ were induced to ovulate with $\mathrm{GnRH}$, but not when such follicles ovulated spontaneously. It is possible that small follicles ovulating spontaneously were competent and secreted adequate amounts of estradiol during proestrus; whereas, small follicles induced to ovulate with GnRH were not sufficiently mature.

Subluteal concentrations of progesterone during the estrous cycle preceding insemination allowed increased frequency of LH pulses resulting in a persistent dominant follicle (Johnson et 
al., 1996; Bridges and Fortune, 2003). In beef cows, larger pre-ovulatory follicles, which maintained dominance for an extended period before the LH surge, reduced conception rate compared to smaller pre-ovulatory follicles (36\% versus 91\%: Breuel et al., 1993). Exposure of the oocyte to high peak frequency of LH induced premature resumption of meiosis (Revah and Butler, 1996; Mihm et al., 1999), and the biochemical and morphological changes in the oocyte in persistent follicles led to reduced fertility in cattle (Mihm et al., 1994; Inskeep, 1995) due to embryo mortality before the 16-cell stage (Ahmad et al., 1995). In contrast, Wurst (2007) did not find age of the oocyte from penultimate as compared to final follicular wave as a factor of embryonic or fetal losses in sheep.

B. Duration of proestrus and subsequent luteal phase. Manipulating the interval from follicle deviation to induced ovulation increased the incidence of short luteal phases and reduced pregnancy rates in dairy cows (Vasconcelos et al., 2001; Peters and Pursley, 2003). Mussard et al. (2003) indicated that reducing the length of proestrus induced subsequent short luteal cycles. Short luteal cycles reduced pregnancy rates regardless of size of the ovulatory follicle (follicles $\geq 10 \mathrm{~mm}$ ), even when cows received a viable embryo on day 7 postestrus (Mussard et al., 2003). Inadequate duration of proestrus might reduce exposure to estradiol prior to ovulation. This limited $E_{2}$ exposure increased responsiveness of the endometrium to oxytocin and the upregulation of $\mathrm{PGF}_{2} \alpha$ led to embryonic death according to Mann and Lamming (2001). However, the studies by Kieborz-Loos et al. (2003) indicate that the role of estrogen may be to establish uterine progesterone receptors, so as to delay secretion of $\mathrm{PGF}_{2} \alpha$. 
CL Maintenance. Silva et al. (2000) demonstrated that the CL, during maternal recognition of pregnancy, is capable of processing $\mathrm{PGF}_{2} \alpha$ to its metabolite (PGFM). Day-13 CL from ewes with viable embryos had greater concentrations and activity of prostaglandin dehydrogenase (PGDH) than day-13 CL from cyclic ewes (Silva et al., 2000). Failure of the conceptus to produce luteotropic signals or inability of the CL to respond to luteotropins could contribute to early embryonic death. However, treatment with progesterone on day 4, 6, and 8 post estrus had no effect on conceptus viability (Faris et al., 2004). High producing dairy cows have increased steroid metabolism that could cause low progesterone blood concentrations and therefore increased loss of embryonic competence (Wiltbank et al., 2002).

Nutritional Stress and Body Condition. The body condition of the ewe at mating and nutrient level postmating have major effects on embryonic survival and fetal birth weight (West et al., 1991a; Meyer, 2002). López-Gatius et al. (2002) indicated that a 1 unit drop in body condition score in dairy cows (BCS; $1-5$ scale) from calving to 30 days postpartum increased the odds ratio for pregnancy loss by 2.41 -fold. Similarly, Silke et al. (2002) observed that cows losing 1 unit in BCS from days 28 to 56 of gestation had a 3.2-fold increase in odds ratio for pregnancy loss in the same period. Therefore, metabolic status of the cow, as evidenced by changes in BCS, affects embryonic and fetal survival. Abecia et al. (1997) found no effect of ewe nutrition on pregnancy rate or embryonic survival after restricting the diet from 2 weeks prior to breeding to 8 days of gestation. Nawaz and Meyer (1991) compared six genotypes; only the Polypay-sired ewes exhibited a significant relationship between body weight and reproductive performance.

The ewe's diet can have detrimental effects on the conceptus (Rhind et al., 1989; James et al., 1992). As reviewed by James et al. (1992), toxic effects of poisonous plants on fetal 
physiology, growth, and development have been observed through ultrasonography (Panter et al., 1987). Ingestion of some poisonous plants by pregnant ewes slowed fetal heart rate with resultant changes in placental function, fetal edema, fetal death, and complete pregnancy losses (Panter et al., 1987). Furthermore, locoweed causes enlargement of the right ventricle of the ovine fetal heart, indicative of congestive right heart failure. As another example, cottonseed contains gossypol that can be toxic to mammalian cells (Danke et al., 1965). High plasma concentrations of gossypol reduced embryo quality and development, and conception rates in cattle and sheep (Kramer et al., 1991; Santos et al., 2003; Villasenor et al., 2008). Cows fed high gossypol diets experienced greater fetal loss, and reduced conception rates were associated with higher plasma gossypol concentrations (Santos et al., 2003).

Low progesterone concentration was a characteristic feature of over-fed ewes (Wallace et al., 1997). Excess nutrition also affects caruncular function. A normal number of caruncles were originally occupied, but fewer continued to develop to their full size, and progesterone transport potential was reduced during the second half of pregnancy in the over nourished ewe (Wallace et al., 1994). Spencer and Bazer (2002) concluded that a high plane of nutrition after ovulation did not influence embryo survival and development (Wallace et al., 2003). However, progesterone plays a major role in controlling the maternal secretion of nutrients, growth factors and immunosuppressive agents required for successful embryo development (Wallace et al., 1997; Spencer and Bazer, 2002).

Maternal Age. There is evidence, at least in some breeds of sheep (Galway: Quirke and Hanrahan, 1977; Romney: McMillan and McDonald, 1985) that embryo survival is lower in ewe lambs than in adult ewes. These latter studies and another by Quirke and Hanrahan (1983), all 
employing embryo transfer, indicated that the impaired embryo survival associated with ewe lambs is attributable to the inherent quality of embryo rather than any deficiency of uterine environment. Among age groups other than ewe lambs, there is little evidence of differences in embryo quality on embryo survival rate (Kleeman et al., 1990).

\section{Environmental Stressors}

A. Management. Pre-implantation embryos may be especially susceptible to losses due to ewe stress occurring 10 to 15 days postmating. One example of this phenomenon, as reviewed by Meyer (2002), is that ewes that were shorn 10 to 15 days post-mating during the mating season often exhibited a break in the lambing pattern. Lambing virtually ceased 132 to 137 days after shearing. Ewes sheared before gestation day 10 or after day 15 seemed to be largely unaffected by shearing stress. Other management practices prior to and during gestation could be lethal to the developing conceptus (Everett-Hincks and Dodds, 2008).

B. Heat Stress. a. Ram. The effects of high ambient temperatures on reproduction have been studied extensively in many species and locations (Dutt and Hamm, 1957). Low fertility of rams early in the season was presumed to be due in part to the higher environmental temperatures, which occurred just prior to and during the early part of the breeding season (Hulet et al., 1956). In the ewe and cow, embryos formed from fertilization of oocytes with spermatozoa that had been exposed to elevated temperatures exhibited reduced survival (Howarth, 1969; Santos et al., 2004).

b. Ewe. Edwards and Hansen (1997) observed that heat stress at the 2-cell stage reduced the number of embryos that developed to the 4-cell stage. Many have determined that heat 
affected not only embryonic survival but fetal survival as well (Hulet et al., 1956; Shelton and Hutson, 1968; Hendy and Bowman, 1974; Lunstra and Christenson, 1981; Hansen et al., 2001). In contrast, extreme cold during gestation can lead to fetal mortality or early postnatal death (Yakubu et al., 2007).

Uterine Capacity. Uterine capacity has been hypothesized to be the limiting factor for the number of embryos that a uterus can support (Nawaz and Meyer, 1991). This appears to be the case in rabbits (Blasco et al., 1994, 2005; Argente et al., 2003; Moce et al., 2004; Peiro et al., 2007).

Anthony et al. (1984) removed the left uterine horn and ovary or just the left ovary from mature ewes to investigate growth capabilities of the uterus and uterine capacity effects on fetal growth in sheep. The removal of the left uterine horns resulted in hypertrophy of the right uterine horns. The conception rate of the ewes without a left uterine horn and ovary was lower than in the ewes without a left ovary. However, no uterine capacity effect was found on fetal growth. Booroola Merino cross ewes as well as other prolific breeds were reported to have lower embryonic and fetal survival (Robinson, 1951; Rhind et al., 1980a, 1980b; Meyer, 1985, 2002; Bradford et al., 1986a, 1986b) so that litter size was increased less than expected despite the increased ovulation rate (Rhind et al., 1980b; Southey et al., 2001; Knight et al., 2003; Devonish et al., 2009). These findings are in agreement with the conclusion by Dixon et al. (2007) that in sheep, partial losses of multiple embryos or fetuses were more common than complete losses of multiples or singletons. 


\section{Genetic Factors}

A. Inbreeding. Inbreeding represents a threat to the genetic potential for fertility in livestock species due to recessive lethal genes that compromise embryonic survival (Van Raden et al., 2006). This is especially true for dairy cattle, in which there has been an increase in inbreeding (Hansen, 2000). Several reproductive traits are adversely affected by inbreeding. Maternal inbreeding decreased the 56-70-day non-return to estrus rates by between $1 \%$ and $2 \%$ per $10 \%$ inbreeding of the dam (Cassell et al., 2003). On the other hand, inbreeding of the embryo reduced the 70 -day nonreturn to estrus rate by $1 \%$ for each $10 \%$ increase in inbreeding of the embryo (Cassell et al., 2003; Van Raden and Miller, 2006). Genetic variation in embryo survival may be attributable to genetic constitution of the embryo itself and or the genetic differences among dams with respect to their ability to provide an appropriate intraovarian and uterine environment.

B. Chromosomal Defects. Genetic causes of embryonic death include chromosomal defects, individual genes and genetic interactions (Van Raden and Miller, 2006). In cattle the 1/29 Robertsonian chromosomal translocation has been a cause of reduced production of males and females heterozygous for $1 / 29$ translocation (Gustavsson, 1979). In the Holstein breed, two major recessive defects affecting embryonic/fetal survival have been detected. Deficiency of uridine monophosphate synthase, a homozygous recessive condition, causes conceptus death at 40-50 days of gestation (Shanks and Robinson, 1989). Another genetic fetal killer is complex vertebral malformation, a lethal recessive condition that causes late fetal death in cattle. This defect was disseminated through the widespread use of the Holstein Carlin-M Ivanhoe Bell as a maternal sire of sires. Cows bred to carrier bulls had a significantly lower non-return to estrus 
rate than those bred to non-carriers following insemination, but were very similar at 28 and 56 days post breeding, indicating that it primarily affected late rather than early fetal mortality (Nielsen et al., 2003; Malher et al., 2006). Arthogryposis multiplex was identified in 2008 by Dr. Jonathan Beever, a geneticist at the University of Illinois. Arthogryposis multiplex is a lethal recessive gene that caused severely phenotypically - deformed calves, which was traced to a carrier Angus bull born in 1979 (Bremer, 2008).

Chromosomal abnormalities can continue to occur after the first cleavage division to give rise to a mixoploid embryo in which some cells are diploid and others exhibit a chromosomal abnormality (Nino-Soto and King, 2004). The percentage of mixoploid embryos increased during the preimplantation period, leading to embryonic death.

C. Gene Mutations. Afolayan et al. (2007) reported genetic variance for scanned fetal numbers and the number of live lambs born. Several genes not related to inbreeding have been expressed from paternal inheritance in sheep, that affect the number of progeny born (Hanrahan et al., 1976; Davis et al., 1982, 1991; Bradford et al., 1986b; Radomska et al., 1988; Nawaz and Meyer, 1991; Boujenane et al., 1991; Meyer and West, 1991; Davis 2004, 2005). Ewes homozygous for the Inverdale and Hanna genes are infertile due to undeveloped ovaries, while heterozygous ewes exhibited increased ovulation rates (Davis et al., 2001).

Breed Differences. In sheep, breed differences in embryo survival as a trait of the ewe have been examined in many studies, based on employing embryo transfer procedures and on estimation of embryo survival using information on ovulation rate and the consequent litter size (Bradford et al., 1989). The general conclusion from embryo transfer studies is that breed of recipient ewe 
does not play an important role in determining embryo survival despite the fact that these studies often involved breeds with very different levels of natural prolificacy (Hanrahan, 1982, 1994). There is some evidence that embryo survival may be better when the Finn breed was used as an embryo recipient (Hanrahan and Piper, 1992). Literature on estimation of embryo survival based on ovulation rate and associated litter size provides a good indication of breed variation in embryo survival. Hanrahan (1994), following an extensive review of literature, suggested that the likely breed differences for ovulation and associated litter size as affected by the probability of embryo survival between breeds are $15 \%, 13 \%$ and $11 \%$ for twin, triplet and quadruplet ovulations, respectively. If the essentially linear relationship between ovulation rate and litter size is the same in all breeds, then a global figure of $12 \%$ probability of embryo loss has been suggested by Hanrahan (1994) as the likely range of breed means for embryo survival adjusted for ovulation rate. Variation among individuals within a population, measured as repeatability of differences in embryo survival, was quite low (5\%) (Hanrahan, 1982; Ricordeau et al., 1986), and consequently the heritability of these differences also was extremely low (Ricordeau et al., 1986). In an attempt to look at breed-type differences, Dixon et al. (2007) classified ewes according to face color (white, mottled and black). Embryonic and fetal losses from day 25 to term were lowest for white-faced ewes (17.7\%), followed by mottled-faced ewes (19.2\%), and occurred most frequently in black- faced ewes (29.0\%). However, Saoud et al. (1984) did not find a significant relationship between ewe fertility and prolificacy and sire breed or ram within breed.

Sire effect. The male gamete influences fertility not only by affecting fertilization rate, but also by imparting characteristics to the embryo that influence its ability to proceed through 
development (Hulet et al., 1956, 1965; Bishop, 1964; Pegorer et al., 2007). Thus, one can observe differences in embryonic mortality between sires in vivo and in vitro ( Morris et al., 2003; Van Raden et al., 2006). Afolayan et al. (2007) reported a sire breed and environment interaction on pregnancy and fertility in sheep.

Humblot and Denis (1986) studied records on 7536 cows to evaluate sire effects on daughter fertility. The reproductive traits studied were: number of services per conception; pregnancy rates after one, two and three services; distribution of intervals between inseminations; and frequency of late embryonic death. The sire effect on services per conception; pregnancy rates after one and two services, and distribution of intervals between inseminations was significant, but no effect was seen for conception rate after three services. The sire-year interaction was found to be a source of variation. An effect of the sire was found on the distribution of returns to estrus after service. However, no evidence of sire effects on late embryonic death was found.

In an 8-year study, involving 1346 ewes originating from one flock, ewes were mated to individual sires to determine the influence of sire on ewe prolificacy (Carr et al., 2000). It was concluded that individual rams impacted the number of lambs born per ewe; therefore the sire of the fetus or potential fetus played a role in ewe prolificacy.

Ultrasonographic Techniques. An ultrasonographic image is composed of an array of picture elements called pixels and in the formation of an image thousands of pixels are involved (Ginther, 1995). These pixels represent reflections of tissue density (Schrick and Inskeep, 1993; Pierson and Adams, 1995). If an organ contains fluid, it does not reflect sound waves and appears black on the screen while tissue with a dense consistency reflects most of the sound 
beam and appears white (Shirley et al., 1978; Schrick and Inskeep, 1993). Real time imaging records echos continuously, allowing fetal leg movements and heart beats to be observed as they occur (Ginther, 1983). If tissue density changes over time, it can be detected by pixel analysis (Pierson and Adams, 1995). This approach can provide more information about developmental changes in organs such as the ovary and uterus (Dixon et al., 2007; Wurst, 2007). However, good quality images are required for successful image analysis. The transducer should be positioned properly and the pressure applied to the organ should be optimum as excessive or inadequate pressure may distort the anatomy of the organ or provide a poor quality image (Shirley et al., 1978).

Ultrasonography is a very useful technique in imaging reproductive organs (Griffin and Ginther, 1992). Ultrasonography use is well described for evaluation of the ovary and uterus in female sheep, cattle and horses (Buckrell et al., 1986, 1988; Pierson et al., 1988; Gearhart et al., 1988; Schrick and Inskeep, 1993). Ultrasonography is noninvasive and does not subject the animal to injury (Buckrell, 1988; Padilla-Rivas et al., 2005; Wurst, 2007). Its use in pregnancy determination was initially in the early fetal stage for diagnosis of pregnancy and the number of viable fetuses (Lindahl, 1971; Deas, 1977; Horvarth et al., 1978; Schrick and Inskeep, 1993). In sheep, pregnancy can be detected accurately and embryo counts can be made with low accuracy by day 20 (Gearhart et al., 1988; Schrick and Inskeep, 1993). Accuracy of pregnancy diagnosis and embryo counts improves as conceptus development progresses. Ultrasonography has provided a way to follow embryonic or fetal losses from about day 25 of the gestational period (Dixon et al., 2007). 


\section{STATEMENT OF THE PROBLEM}

Land resources and breeding sheep numbers in the United States are on the decline due to suburban spread and economic hardships, along with poor production per ewe unit. The National Agricultural Statistics Service (NASS) reported a 2007 lambing rate of 1.10 lambs per ewe. That was down 1 percent from 2006 (1.12) and the 2009 lambing rate was down slightly from the 1.05 lambs per ewe in 2008 (NASS, 2011) (Figure 1). One way many have tried to solve this problem is by utilizing accelerated lambing programs. Breeding ewes more frequently has not solved the problem. Many high quality carcass breeds of sheep will not breed in profitable proportions during the anestrous interval; other breeds that exhibit less seasonality have poor carcass qualities and value. Therefore, producers profit less per animal unit, not to mention the increase in time, labor and other expenses required for accelerated lambing programs. Therefore, the numbers of live lambs born per ewe at each lambing need to be improved without increasing the input cost. The ewe has been studied in great detail in relation to conceiving and maintaining pregnancy. Based upon the literature reviewed, many factors play a role in ewe prolificacy, despite the high rate of fertility (90-95\%). The quality of the oocyte and cyclic status are extremely important for conceptus survival. Nutrition, genetics, temperature, age of the gametes, body condition of the dam, hormone concentrations, diseases, and other factors trigger mechanisms that lead to loss of approximately half of all potential conceptuses before natal development can be completed (Dixon et al., 2007). Synchronization of estrus also can lead to increased embryonic loss. As the ovulation rate increases, numbers of embryonic and fetal mortalities increase. 


\section{Lamb Crop \\ United States, 1989-2006}

(000) Head

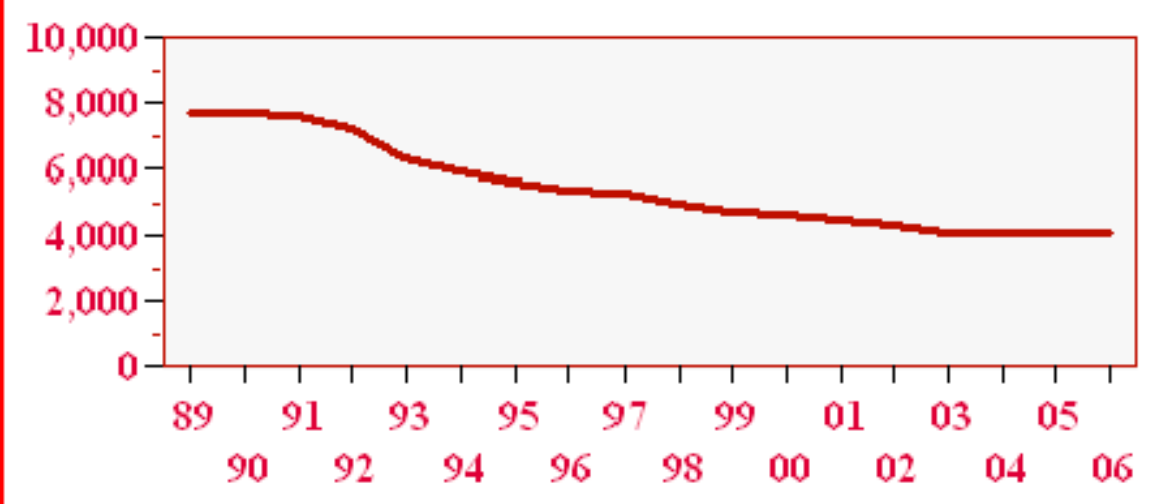

USDA-NASS

2-2-2007

Figure 1. USDA-NASS statistical trend of the number of lambs born in the United States from 1991 through 2010 (source USDA web site).

The embryo is responsible for biochemical signaling to elicit pregnancy recognition. The embryo has some capacity to direct the maternal system to produce a local environment that serves the needs of the conceptus. Development during the embryonic period of pregnancy (until about d 42 of pregnancy) is a complicated phenomenon, involving among other processes, embryonic genome activation, compaction, blastocyst formation, elongation of the trophoblast, secretion of interferon- $\tau$ to help maintain the corpus luteum, differentiation of placental tissues, and development of the inner cell mass into the embryo and then the fetus (Hansen et al., 1999). Any of these processes can fail because of some intrinsic defect in the embryo, whether derived originally from the oocyte or sperm, or originating subsequent to zygote formation. From 25 days to term, 3 to 4 percent of embryos or fetuses were lost every 20 days (Dixon et al., 2007). 
Very few authors have studied the effect of the sire beyond differentiation, development, spermatogenesis, fertilization and early embryo survival. It is well documented that heat stressed spermatozoa can directly lead to poor conception, abnormalities and embryonic death at the morula, blastocyst, and attachment stages of early embryonic life. A major limitation in direct selection for increased sire competance is that males need to be selected mainly on the performance of their female relatives, and females do not express lambing traits until at least one or two years of age. This selection process can be accelerated by studying prenatal survival ability of each individual ram's progeny. This can be accomplished by using real time ultrasonography as a non-invasive method of confirming the number of live embryos by observation of the conceptus heartbeat. The objective of the present study was to identify occurrence of late embryonic and fetal mortality in relation to individual sires and to explore possible explanations for the phenomena.

\section{MATERIAL AND METHODS}

Animals. Nine hundred and eighty diagnosed pregnant ewes that were bred during the anestrous season (May, June, July, or Aug.), early estrous season (Sept.), or estrous season (Oct., Nov., or Dec.) were studied on 10 farms. The West Virginia farms participating in this study were Snowy Creek Dorsets in Terra Alta, WVU Reymann Memorial Farm at Wardensville, WVU's Morgantown teaching flock, and the Fulk Farm in Aurora. Other farms, Cornell University at Ithaca, New York, Ohio State University at Wooster, Ohio, University of Maryland Eastern Shore in Prince Anne, Maryland, Happy Hampshire Farm in Oakland, Maryland and the University of Wisconsin-Madison at Arlington and Spooner, Wisconsin. Ewes were exposed to individual rams on each farm. A total of 67 rams of 12 different breeds were studied. The ram 
breeds were Dorset, Dorper, Katahdin, Lacaune, East Friesian, Romney, Rambouillet, Targhee, Polypay, Texel, Suffolk, and Hampshire. Any ewes that died or were culled between the time of pregnancy diagnosis and lambing were removed from the study (and not included in the total 980 ewes). The ewes studied were composed of 12 breeds or crosses, including Dorset (269), Dorper (7), Katahdin (108), Lacaune (78), East Friesian (42), Romney (35), Targhee (18), Polypay (69), Texel (47), Suffolk (38), Hampshire (227) Rambouillet (9), and Rambouillet carrying the Booroola gene (17). Ewe age was determined at the time they were bred.

Synchronization Protocol. Estrus was synchronized and/or induced for five of the 10 flocks. Ewes in 4 flocks during the anestrous season received an injection (i.m.) of $25 \mathrm{mg}$ of progesterone at ram introduction followed by an injection (i.m.) of $20 \mathrm{mg}$ of prostaglandin $\mathrm{F}_{2} \alpha$ (Lutalyse, Pharmacia Animal Health, Kalamazoo, MI) 14 days later. One flock during the estrous season received $20 \mathrm{mg} \mathrm{PGF} 2 \alpha$ only at the time of ram introduction.

Pregnancy Determination. Pregnancy determination and counts of embryos or fetuses were made at a single observation by ultrasonography using an Aloka 500 (Corometrics Medical Systems, Wallingford, CT) with a $7.5 \mathrm{mHz}$ linear transrectal probe as described by Schrick and Inskeep (1993) for embryos or a $3.5 \mathrm{mHz}$ transabdominal sector probe as reviewed by Hesselink and Taverne (1994) for sheep fetuses and reported by Trapp and Slyter (1983) for goat fetuses. The probe was wiped clean after each animal and coated with a carboxymethyl cellulose lubricant before scanning the next animal. Transrectally examined ewes were restrained in a dorsal recumbent position within a tilting squeeze chute for pregnancy determination and embryo counts. This practice caused no harm to the conceptus and minimal stress to the ewe (Wurst, 
2007). The transabdominally examined ewes were examined in a standing position restrained by a head chute or by a person restraining the ewe by the head and neck in a gentle but firm manner.

Factors involved in embryonic and fetal mortality. Effects of various factors on embryonic and fetal survival or loss were measured first as lambs born per ewe in relation to classification at time of scanning as having single or multiple embryos or fetuses. This less precise approach was necessitated because of an unusual number of triplet births in ewes in which only two potential progeny had been recorded. The distribution and extent of those diagnostic errors are presented in Table 1. Therefore, a number of animals could have experienced undetected losses and still delivered twins. Factors investigated were breed-type of ram, individual ram, season ewe was bred, breed-type of the ewe, age of the ewe and interactions among these factors on individual farms. After removal of ewes that had more lambs than diagnosed $(n=166)$, a second analysis was conducted. The same factors were examined for effects on detected losses in the remaining ewes.

\section{STATISTICAL ANALYSIS}

Factors investigated for effects on numbers of lambs born were number of embryos or fetuses at diagnosis (single or multiple), individual ram, breed-type of ram, season ewe was bred, breed-type of the ewe, age of the ewe, embryo type (purebred or crossbred), farm and interactions among these factors. The GLM procedure of SAS (SAS Institute; Cary, NC; 9.1) was used to examine the main effects and interactions of these factors on the pregnancy outcome. All variables tested were confounded with farm due to the fact that not all farms contained all breeds, and individual rams were confined to individual farms. Similarly, breed of ewe was 
Table 1. Characterization of the data collected by farm.

\begin{tabular}{|c|c|c|c|c|c|c|c|c|c|c|}
\hline Farm & $\begin{array}{l}\text { No. ewes } \\
\text { pregnant }\end{array}$ & $\begin{array}{l}\text { No. of } \\
\text { ewes } \\
\text { w/more } \\
\text { lambs } \\
\text { born than } \\
\text { counted at } \\
\text { diagnosis }\end{array}$ & $\begin{array}{l}\text { No. of ewes } \\
\text { w/ } \\
\text { documented } \\
\text { loss }\end{array}$ & $\begin{array}{l}\text { No. of ewes } \\
\text { w/ } \\
\text { documented } \\
\text { partial loss }\end{array}$ & $\begin{array}{l}\text { No. of ewes } \\
\text { w/ } \\
\text { documented } \\
\text { total loss }\end{array}$ & $\begin{array}{l}\text { Actual } \\
\text { lambs } \\
\text { born }\end{array}$ & & $\begin{array}{l}\text { No. } \\
\text { lambs } \\
\text { per } \\
\text { ewe } \\
\text { bred }\end{array}$ & $\begin{array}{l}\text { No. } \\
\text { lambs } \\
\text { per ewe } \\
\text { lambing }\end{array}$ & $\begin{array}{l}\text { Percent of } \\
\text { ewes with } \\
\text { more lambs } \\
\text { born than } \\
\text { documented }\end{array}$ \\
\hline 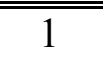 & 2251 & 19 & $4 \overline{47}$ & 445 & 2 & "459 & & 1.83 & 1.84 & 7.6 \\
\hline 2 & 102 & 22 & 27 & 9 & 18 & 129 & & 1.26 & 1.54 & 21.6 \\
\hline 3 & 35 & 8 & 7 & 6 & 1 & 59 & & 1.69 & 1.74 & 22.9 \\
\hline 4 & 81 & 18 & 9 & 9 & 0 & 138 & & 1.70 & 1.7 & 22.2 \\
\hline 5 & 132 & 33 & 22 & 11 & 11 & 186 & & 1.41 & 1.54 & 25 \\
\hline 6 & 93 & 18 & 17 & 12 & 5 & 170 & & 1.83 & 1.93 & 19.4 \\
\hline 7 & 105 & 7 & 16 & 6 & 10 & 164 & & 1.56 & 1.72 & 6.7 \\
\hline 8 & 26 & 9 & 5 & 2 & 3 & 49 & & 1.88 & 2.13 & 34.6 \\
\hline 9 & 110 & 32 & 35 & 13 & 22 & 144 & & 1.31 & 1.64 & 29.1 \\
\hline 10 & 45 & 17 & 10 & 6 & 4 & 87 & & 1.93 & 2.12 & 37.7 \\
\hline Total & $\mathrm{n}=980$ & 183 & 195 & 119 & 76 & 1585 & Mean & 1.62 & 1.75 & 22.4 \\
\hline
\end{tabular}


confounded with farm, individual rams and breed of ram. Also, not all farms had sheep bred in all estrous seasons. For both ewes and rams, breeds were grouped into 4 phenotypic categories (black-faced, white-faced, hair-type, or milking breeds). Crossbred mottled-faced ewes were categorized as black or white-faced, based upon the breed of the sire. The months ewes were bred were pooled to represent the anestrous season (May, June, July, or August), early estrous season (September), or estrous season (October, November, or December). Due to confounding among factors, each independent variable of interest was analyzed individually, with number of embryos at diagnosis and interaction with that number included in each model ( $\mathrm{n}=980$ ewes from 10 farms). The analysis of variance table for individual ram is illustrated as an example of the model in Table 2. Most farms included all age groups of ewes, except some farms provided only partial data on ewe age. Therefore, to determine the effect of ewe age, data from only ewes that included age data were included in the analysis, with a total of 697 ewes.

Table 2. Analysis of variance for effects of ram (service sire), number of diagnosed embryos and their interaction on number of lambs born.

\begin{tabular}{cccccc}
\hline & DF & $\begin{array}{c}\text { Sum of } \\
\text { Squares }\end{array}$ & $\begin{array}{c}\text { Mean } \\
\text { Square }\end{array}$ & F Value & Pr $>$ F \\
\hline Model & 124 & 223.70 & 1.80 & 3.75 & $<0.0001$ \\
Error & 855 & 411.57 & 0.48 & & \\
Corrected & 979 & 635.27 & & & \\
Total & & Type III & & & \\
& & 46.13 & 46.13 & 95.83 & $<0.0001$ \\
Embryo & 1 & 53.85 & 0.82 & 1.69 & 0.0007 \\
Ram & 66 & 39.75 & 0.70 & 1.45 & 0.0189 \\
Ram*Embryo & 57 & & & & \\
R-Square & Coefficient & Root MSE & $\begin{array}{c}\text { Mean No. } \\
\text { Range/Ram }\end{array}$ & \\
& Variable & & Born & in No. Born & \\
0.35 & 42.87 & 0.69 & 1.62 & $0.70-2.45$ & \\
\hline
\end{tabular}


A second analysis evaluated effects of the variables of interest on the detected losses of pregnancy in ewes $(n=814$ ewes). This analysis was carried out in the same manner as for number of lambs born.

\section{RESULTS}

Embryonic and fetal losses were documented after the initiation of placentation (Table 3). The median day of examination ranged from 29 to 53 as estimated from the lambing dates. As expected, ewes diagnosed with multiple lambs delivered more lambs than those diagnosed with singles (Single vs. multiple; $\mathrm{P}<0.0001$ ). As shown in Table 4, $20 \%$ of ewes had documented losses; however, $29.4 \%$ of embryos or fetuses were lost. Data are presented first for the number of lambs born and second for losses in ewes that had an equal number or fewer lambs born than were diagnosed.

Table 3. Median day of gestation ewe was examined, number of ewes and percent of ewes that had more embryos or fetuses than documented per farm.

\begin{tabular}{rccccccc}
\hline \hline Farm & Ewes & Day & Percent & Farm & Ewes & Day & Percent \\
\hline \hline 1 & 251 & 39 & 8 & 6 & 93 & 33 & 19 \\
2 & 102 & 43 & 22 & 7 & 105 & 53 & 7 \\
3 & 35 & 53 & 23 & 8 & 26 & 35 & 35 \\
4 & 81 & 29 & 22 & 9 & 110 & 32 & 29 \\
5 & 132 & 36 & 25 & 10 & 45 & 36 & 38 \\
\hline \hline
\end{tabular}

Effect of individual rams (service sires) on the number of lambs born. The rams' effect on late embryonic and fetal losses was investigated along with other potential factors. Individual rams had a significant effect on the number of lambs born $(\mathrm{P}<0.001)$. Ewes bred to individual rams and diagnosed pregnant delivered an average of 0.70 lambs to 2.45 lambs born per ewe. In 
Table 4. LS mean's of documented embryonic/fetal losses within individual farms as percentages of the total numbers of embryos or fetuses diagnosed by ultrasonography ${ }^{\mathrm{a}}$.

\begin{tabular}{|c|c|c|c|c|c|c|c|c|c|c|}
\hline Farm number & 1 & 2 & 3 & 4 & 5 & 6 & 7 & 8 & 9 & 10 \\
\hline All documented losses & $0.16^{\mathrm{bc}}$ & $0.24^{\mathrm{b}}$ & $0.36^{\mathrm{cd}}$ & $0.28^{\mathrm{b}}$ & $0.23^{\mathrm{bc}}$ & $0.35^{\mathrm{c}}$ & $0.15^{\mathrm{b}}$ & $0.70^{\mathrm{d}}$ & $0.36^{\mathrm{c}}$ & $0.60^{\mathrm{d}}$ \\
\hline $\begin{array}{c}\text { Loss of a single embryo or } \\
\text { fetus }\end{array}$ & $0.06^{\mathrm{b}}$ & $0.42^{\mathrm{cd}}$ & $0.60^{\mathrm{d}}$ & $0.48^{\mathrm{cd}}$ & $0.38^{\mathrm{cd}}$ & $0.51^{\mathrm{d}}$ & $0.18^{\mathrm{bc}}$ & $1.0^{\mathrm{e}}$ & $0.50^{\mathrm{d}}$ & $0.57^{\mathrm{d}}$ \\
\hline $\begin{array}{l}\text { Loss of multiple embryos or } \\
\text { fetuses }\end{array}$ & 0.26 & 0.07 & 0.13 & 0.09 & 0.07 & 0.19 & 0.12 & 0.25 & 0.21 & $0.62^{\mathrm{b}}$ \\
\hline
\end{tabular}

\footnotetext{
"a Based on data from ewes for which no gains in litter size over number of embryos or fetuses were observed and recorded at diagnosis by ultrasonography.

${ }^{\text {bcde }}$ Means within a row without common superscript differ $(\mathrm{P}<0.05)$. Farm 10 differs from all other farms $(\mathrm{P}<0.05)$.
} 
addition, differences among rams varied for ewes diagnosed with single or multiple embryos (interaction of ram $\mathrm{X}$ number of diagnosed embryos, $\mathrm{P}<0.02$ ). The distribution of rams according to each diagnostic category for numbers of lambs born is shown in Figure 2.

Effect of breed-type of ram on the number of lambs born. The main effect of breed of ram was not statistically significant, but there was an interaction of breed of ram by number of embryos at diagnosis $(\mathrm{P}<0.0002)$. Ewes diagnosed with a singleton from the black-faced rams had 1.23 lambs born, and ewes diagnosed with multiple embryo or fetuses delivered 1.94 live lambs per ewe. For white-faced rams, ewes with singletons at examination gave birth to 1.16 lambs, and ewes confirmed to be impregnated with multiples had 2.04 lambs per ewe. Ewes bred to dairytype-rams that were diagnosed with singletons actually gave birth to 0.95 lambs per ewe, and ewes examined with multiples had 1.96 lambs born per ewe. Ewes diagnosed with a singleton from hair-type-rams had 1.29 lambs born, but ewes diagnosed with multiple embryos/fetuses delivered only 1.60 live lambs per ewe.

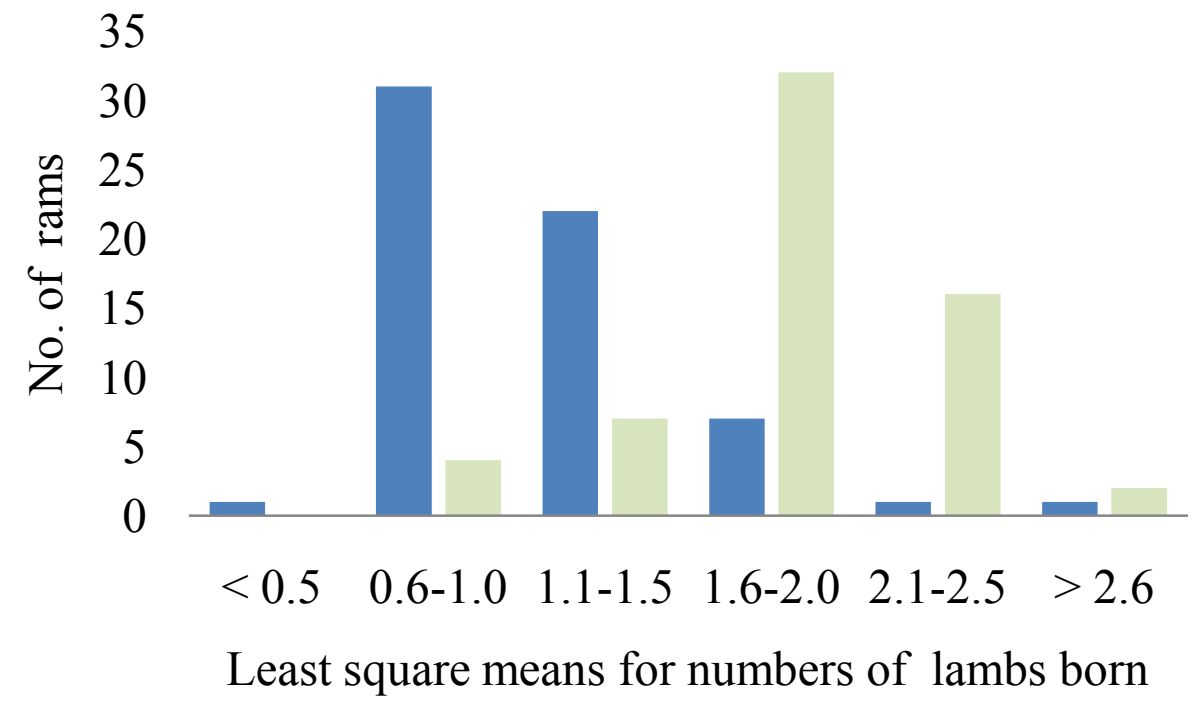

Figure 2. Distribution of rams in relation to number of lambs born. 
Effect of breed-type of ewe on the number of lambs born. There was no main effect of ewe breed, but there was a ewe breed by embryo interaction ( $\mathrm{P}<0.001)$. Lambs born to black-faced ewes with singletons (1.23) or to white-faced (1.16) or hair- type ewes (1.31) were greater than for dairy ewes with singletons (0.95). For diagnosed multiple embryos, hair-type ewes had fewer multiple births (1.64 lambs born) than the other three breed types (1.91 to 2.04).

Effect of age of ewe on the number of lambs born. There was a main effect of age of ewe $(\mathrm{P}<$ 0.0001 ) and no interaction with number of diagnosed embryos. In general, number of lambs born increased with age (Figure 3). The 5-year-old and older ewes had a mean of 1.96 lambs born per ewe, which was significantly greater than the ewe lambs, and the 1-and 2-year-old ewes.

Effect of farm on the number of lambs born. The number of lambs born varied significantly with farm $(\mathrm{P}<0.0001)$ as well as with the farm by number of diagnosed embryos interaction (Figure 4). Ewes on farm 8 were the most prolific overall with 1.85 lambs born per ewe. The mostly hair type sheep on farm 9 delivered only1.33 lambs per ewe.

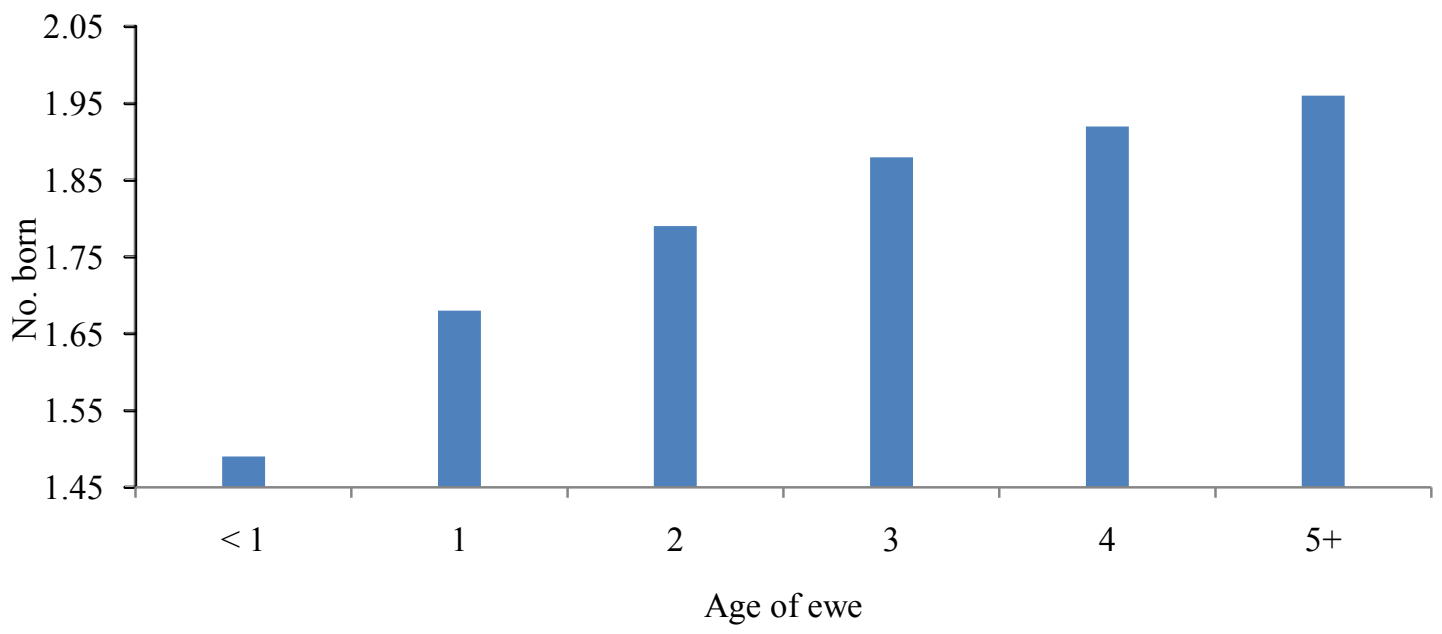

Figure 3. LS mean of the number of lambs born in relation to the age of the ewe. 


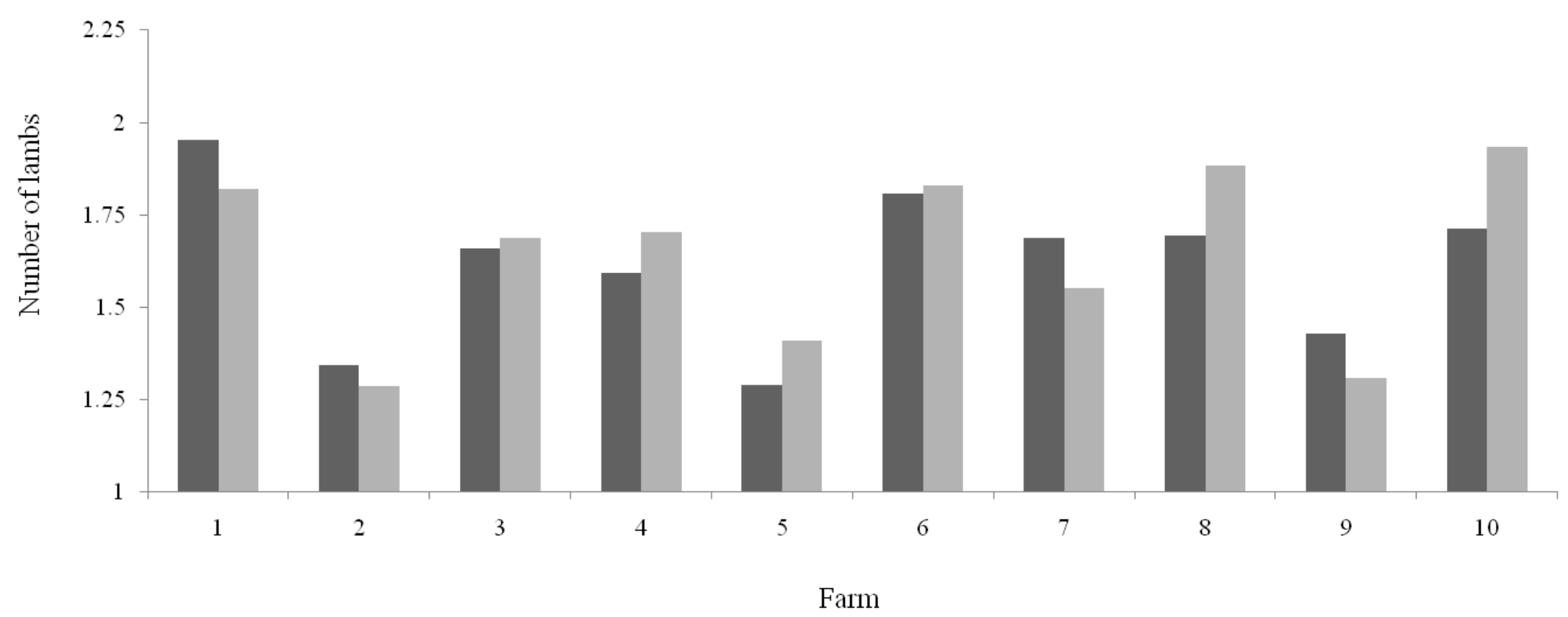

Figure 4. The estimated number of lambs per ewe and the actual number of lambs born per ewe on each farm.

- Estimate of lambs per ewe

- Actual lambs per ewe 
Effect of season bred on the number of lambs born. Ewes bred during the estrous season (October, November, or December) had relatively fewer lambs born per ewe (1.48) than ewes bred during the anestrous (1.61) or early estrous seasons (1.64), but there was no significant difference among seasons $(\mathrm{P}=0.42)$.

Factors affecting losses in ewes in which diagnosis was not known to have underestimated numbers of potential offspring. Losses were greater for single embryos (least squares mean $38.8 \%$ ) than for multiple embryos (least squares mean 21.7\%).

Effect of individual rams on the number of documented embryonic/fetal losses. Individual rams to which ewes were bred had a significant effect on the embryo's ability to complete gestation (Table 5). There was a ram by number of diagnosed embryos interaction $(<0.005)$, indicating that ewes bred to some rams were more apt to lose single pregnancies, whereas ewes bred to other rams were more apt to lose one or more embryos or fetuses from a multiple pregnancy.

Effects of breed-types on the number of documented embryonic/fetal losses. Breed of ram (service sire) affected $(<0.05)$ late embryonic and fetal death. Ewes bred to white-faced rams (20\%) or dairy-type rams (21\%) lost fewer embryos or fetuses than those bred to black-faced (30\%) or hair-type (42\%) rams, which did not differ significantly. Greater complete losses of single embryos or fetuses in ewes bred to black-faced or hair-type rams caused a tendency $(\mathrm{P}<0.09)$ for an interaction of ram breed with number of embryos at diagnosis.

Breed of ewe affected $(<0.05)$ late embryonic and fetal death. Hair-type ewes $(46 \%)$ lost more $(\mathrm{P}<0.02)$ documented embryos or fetuses from the time of examination to birth than black-faced 
Table 5. Percentages of documented embryonic/fetal loss for individual sires ${ }^{\text {a }}$.

Categories of embryonic/fetal losses for individual sires \%

$0 \quad 4-10$

$11-15 \quad 16-20$

21-30
$41-78$

No. of rams in each category 9 8 13 12 13 6 6

No. of ewes sampled $72 \quad 132$ 177 195 270 83 64

Average no. of ewes per ram in each category $8 \quad 15$ 14 17 21 14

${ }^{\mathrm{a}}$ Based on data from ewes for which no gains in litter size over number of embryos or fetuses observed were recorded at diagnosis by ultrasonography. 
(27\%), white-faced (20\%), or dairy-type (25\%) ewes. Greater losses of a single embryo than of multiple embryos were observed in black-faced ( $37 \%$ vs $18 \%$ ) and hair-type (64\% vs $27 \%$ ) ewes than in the other breeds, as depicted by an interaction of breed and number of diagnosed embryos $(\mathrm{P}<0.03)$ per ewe. Complete embryonic or fetal death was observed in 76 ewes and partial losses were documented in 195 ewes.

Effect of ewe age on the number of documented embryonic/fetal losses. The age of ewe had a significant effect on embryonic and fetal losses, with no interaction with number of diagnosed embryos. The ewe lambs lost significantly fewer embryos or fetuses (less than 1\%) than any other age group $(\mathrm{P}<0.05)$. Losses increased with age as shown in figure 5, with the greatest losses occurring in the oldest ewes, although they did not differ from 3- and 4- year-old ewes.

Effect of embryo breed-type on the number of documented embryonic/fetal losses. Purebred embryos or fetuses were lost less often (24\%) than crossbred embryos (36.4\%; $\mathrm{P}<0.002)$. There was no interaction with diagnosed number of embryos.

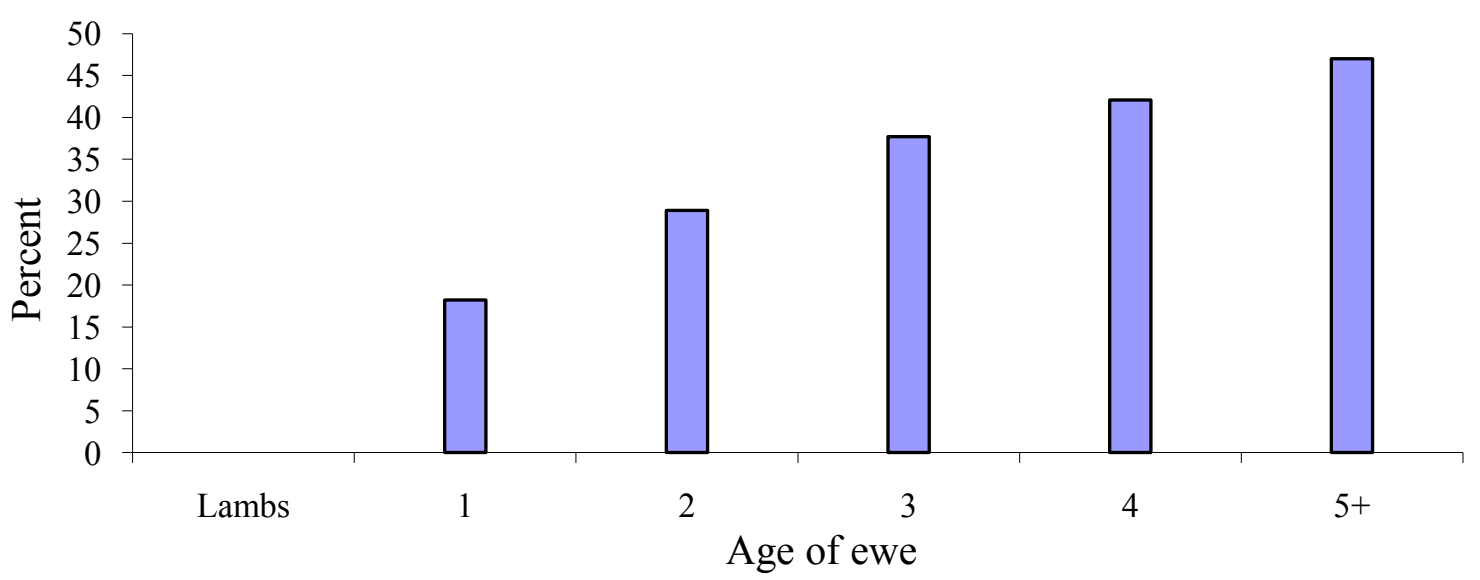

Figure 5. LS means of embryonic or fetal losses in relation to ewe age. 
Effect of farm on the number of documented embryonic/fetal losses. Farm and farm by embryo interaction were significant $(\mathrm{P}<0.0001)$, as illustrated in Table 4 .

\section{DISCUSSION}

Effects of breed-type of service sire. The data showed effects on embryonic and fetal mortality for both individual rams and the breed of ram. Individual rams that ewes were bred by (service sires) played a major role in the number of fetuses that were retained to term. Morris et al. (2003) found individual service sire differences during early embryonic development. Once differences in embryonic development rates were detected, they persisted throughout the in vitro culture period. Those findings were reflected in vivo by reduced embryonic survival rates. Morris et al. (2003) concluded that service sire differences were significant during embryonic development prior to embryonic genome activation, but observed no differences among rams in the total number of lambs born, in contrast to the current results.

Bishop (1964), in a review, stated that there were significant differences in male fertility among bull breeds. Humblot and Denis (1986) did not find a service sire effect on late embryonic death in cattle. Carr et al. (2000) on the other hand, determined from an 8-year study that individual rams impacted ewe prolificacy. Afolayan et al. (2008) found that the ewe's service sire breed had an effect on the number of lambs born to Merino ewes. Therefore, losses appear to be due, in part, to the conceptus's paternal contribution (Carr et al., 2001). The current study used nearly all purebred rams, therefore hybrid vigor of the sire could not be examined. The individual service sire differences in numbers of lambs born or in documented losses in this study were interpreted to be due, at least in part, to genetic factors. However, it is well 
documented that environmental factors play a major role in the success of reproduction (Rich and Alliston. 1970; Meyer, 2002).

Relationships to breed-type and age of dam. Few studies have examined ewe prolificacy from the point of view of the sire of the dam. Most of the ewes examined in the current study were purebred. Sire breed-type of dam, as classified into four groups, had no main effect on number of lambs born. However, the maternal contribution to number of lambs born was determined in part by the dam's age and breed-type interaction. In a study by Saoud et al. (1984), breed of dam, as classified by her sire, was not a statistically significant factor. Cassell et al. (2003) and Hanrahan and Piper (1992) documented that the ewe's genotype had an impact on the competency of the conceptus. It has been well documented that the dam's age has a direct effect on ovulation rate and on the number of live lambs born (Quirke and Hanrahan, 1977, 1983; McMillan and McDonald, 1985). In contrast to many studies that portray ewe prolificacy as curvilinear with age, the results of the current study demonstrated a progressive linear increase of the number of lambs born per ewe with age. The pattern of ewe prolificacy with age in this study was similar to that seen by Sidwell et al. (1962) in five breed types. However, it does not agree with Turner and Dolling (1965) who found a curvilinear pattern. Inskeep et al. (1967) found similar results as Turner and Dolling (1965) in a 20-year study involving repeatability of ewe prolificacy. The current results may reflect flock selection for prolificacy and longevity, or culling of nontwinning older ewes in many flocks. The number of ewes was fewer at the older ages, indicating that only the most productive ewes were being retained beyond 5-years of age.

In the present study, late embryonic and fetal losses increased with age in the same pattern as number of lambs born. This result may reflect the increase in losses seen with 
increased ovulation rates (Meyer, 1985; Knights et al., 2003; Dixon et al., 2007; Devonish et al., 2009). Although the number born increased with age, efficiency of maintenance of embryos or fetuses decreased with age. Thus, ewe lambs exhibited less apparent pregnancy wastage, and therefore, were the most efficient. In contrast, Kleeman et al. (1990) and Quirke and Hanrahan (1983) reported that ewe lambs had greater embryonic loss and there was very little variation in all other age groups. As expected, a greater percentage of the ewe lambs were carrying singletons, and complete losses of singles were low in other studies (Dixon et al., 2007).

It was not determined whether specific individual breeds within the breed type and age categories affected litter size. In this study, black-faced ewes had fewer complete embryonic and fetal losses than white-faced ewes. Hair-type ewes had the greatest percentage of ewes (30.7) with documented embryonic and fetal wastage, and the most efficient ewes were the milkingtype (15.7\% documented losses). In contrast, Dixon et al. (2007) found that white-faced ewes retained the conceptus to term at a higher rate than black-faced ewes. Possible explanations for the ewe breed-type differences included the time of gestation that the conceptus were counted or differences in uterine efficiency or inherent embryo quality. Negative relationships between ovulation rate and lambs born per ovulation have been reported in numerous studies (Meyer, 1985; Knights et al., 2003; Dixon et al., 2007). It is speculated that uterine capacity may have influenced the number of lambs born per ewe through the inability to sustain additional embryos, as was believed by Hulet et al. (1968). Nawaz and Meyer (1991) and Meyer et al. (1994) observed differences among breed-types with greater uterine efficiency in genotypes known to have larger litter sizes. 
Effects of embryo type. Most studies have considered the parentage breed types instead of the breed types of the embryos. Van Raden and Miller (2006) reported that the conceptus genotype in cattle was a major player in pregnancy retention to term. Ewes impregnated with crossbred embryos experienced greater late embryonic and fetal mortality than ewes with purebred embryos in this study. Differences in mortality among ram breeds were observed when individual purebred rams were bred to ewes of another breed (Afolayan et al., 2008), but that study did not include purebred embryos. Those results agree with the dogma that higher ovulation rates are correlated with greater embryonic and fetal wastage, as statistically there was no difference in the number of lambs born. A hybrid vigor response by the embryo was expected, because Sidwell et al. (1962) had observed increased prolificacy and overall reproduction as breed type changed from purebred to 3 - and 4-way crosses. The unusual findings in this study should be investigated in greater detail for a better understanding as to why the crossbred conceptus was more likely to be lost.

Partial vs. complete losses. In agreement with Dixon et al. (2007), ewes in the current study experienced partial losses more frequently than total pregnancy failure. In this study, $20 \%$ of the ewes that did not lamb more offspring than observed at diagnosis experienced partial or total late embryonic or fetal loss. Eight percent of these ewes experienced total pregnancy failure and $11 \%$ lost one embryo or fetus. One percent of these ewes lost multiple embryos or fetuses, with at least one fetus being retained to term.

Seasonal factors. Surprisingly, ewes bred during the estrous season did not have more lambs born than ewes bred during the anestrous or late estrous seasons. This result is in contrast to most 
reports in the literature. Hulet et al. (1968) and Al-Shorepy and Notter (1997) suggested that seasonal differences in the number of lambs born are due to ovulation rate. The ovulation rates normally peak during the estrous season, therefore one might have expected more wastage. But statistically, there were no seasonal differences in embryonic and fetal death. Environmental heat and cold stress have negative impacts on late embryonic and fetal survival (Knight et al., 1995; Hansen et al., 2001; Yakubu et al., 2007).

Accuracy of counts of embryos or fetuses. The underestimates of number of conceptuses in 183 of 980 ewes studied were a cause for concern. These underestimates occurred more often in ewes scanned either very early or very late in gestation, and more often in some flocks than in others. Accuracy of the counts was believed to depend partially on the position of the embryo or fetus and stage of gestation, and partially on the experience of the examiner. This interpretation is supported by the conclusion by Schrick and Inskeep (1993) that accuracy of embryo counts was greatest around d 30 of gestation, possibly due to the appropriate size and location of the embryo or fetus within the uterine horn.

\section{CONCLUSIONS}

In conclusion, the service sire influenced the ability of the conceptus to develop to term. Although, much of the paternal role is still a mystery, careful ram selection based on prior records might decrease embryonic and fetal wastage by improving conceptus competence genetically. The individual sire's influence on the conceptus needs to be investigated further to better understand the mechanisms controlling the paternal factors that affect embryonic and fetal wastage in sheep. 


\section{LITERATURE CITED}

Abecia J. A., J. M. Lozano, F. Forcada, and L. Zarazaga. Effect of the level of dietary energy and protein on embryo survival and progesterone production on day eight of pregnancy in Rasa Aragonesa ewes. Anim. Reprod. Sci. 1997, 48: 209-218.

Afolayan, R. A., N. M. Fogarty, A. R. Gilmour, V. M. Ingham, G. M. Gaunt, and L. J. Cummins. 2008. Reproductive performance and genetic parameters in first cross ewes from different maternal genotypes. J. Anim. Sci. 86:804-814.

Ahmad, N., F. N. Schrick, R. L. Butcher, and E. K. Inskeep. 1995. Effect of persistent follicles on early embryonic losses in beef cows. Biol. Reprod. 52:1129.

Alliston, C. W., and L. C. Ulberg. 1961. Early pregnancy loss in sheep at ambient temperatures of $70^{\circ}$ and $90^{\circ} \mathrm{F}$ as determined by embryo transfer. J. Anim. Sci. 20:608-613.

Al-Matubsi, H. Y., and R. J. Fairclough. 2001. Effect of finadyne on oestradiol-induced ovarian oxytocin and uterine PGF2alpha secretory systems on day 15 after oestrus in ovarian autotransplanted ewes. Reproduction 121: 429-434.

Al-Shorepy, S. R., and D. R. Notter. 1997. Response to selection for fertility in a fall-lambing sheep flock. J. Anim. Sci. 75:2033-2040.

Amoroso, E. C. 1951. The interaction of the trophoblast and endometrium at the time of implantation in the sheep. J. Anat. 85:428-429.

Anthony, R. V., R. O. Parker, C. C. Kaltenbach, and T. G. Dunn. 1984. Uterine and fetal growth following unilateral hysterectomy-ovariectomy in ewes. Biol. Neonate 46:14-19.

Antoniazzi, A. Q., Luiz E. Henkes, R. C. Bott, R. Ashley, J. Bruemmer, G. D. Niswender, G. Moss, B. Alexander, J. F. C. Oliveira, Joao F. C., T. E. Spencer, F. W. Bazer, and T. R. Hansen. 2009. Endocrine action of interferon-tau on the corpus luteum in sheep: implication for antiluteolytic and luteotrophic mechanisms. (Abstract) Bio. Reprod. 81:573.

Argente, M. J., M. A. Santacreu, A. Climent, and A. Blasco. 2003. Relationships between uterine and fetal traits in rabbits selected on uterine capacity. J. Anim. Sci. 81:1265-1273.

Arroyo, L. J., J. Gallegos-Sanchez, A. Villa-Godoy, J. M. Berruecos, G. Perera, and J. Valencia. 2007. Reproductive activity of Pelibuey and Suffolk ewes at $19^{\circ}$ north latitude. Anim. Reprod.

Sci. 102:24-30.

Ashworth, C. J., D. I. Sales, and I. Wilmut. 1989. Evidence of an association between the survival of embryos and the periovulatory plasma progesterone concentration in the ewe. J. Reprod. Fertil. 87:23-32.

Ayalon, N. 1978. A review of embryonic mortality in cattle. J. Reprod. Fertil. 54:483-493. 
Ayalon, N. 1981. Embryonic mortality in cattle. Zuchthygiene 16:97-109.

Bazer F. W. 1975. Uterine protein secretions: relationship to development of the conceptus. J. Anim. Sci. 41(5):1376-1382.

Bazer F. W., and N. L. First. 1983. Pregnancy and parturition. J. Anim. Sci. 57 (Suppl. 2):425460 .

Berndtson, W. E., and C. Desjardins. 1974. The cycle of the seminiferous epithelium and spermatogenesis in the bovine testis. American Journal of Anatomy 140:167-180.

Bishop, Marcus W. H. 1964. Paternal contribution to embryonic death. Review. J. Reprod. Fertil. 7: 383-396.

Blasco, A., M. J. Argente, C. Haley, and M. A. Santacreu. 1994. Relationships between components of litter size in unilaterally ovariectomized and intact rabbit does. J. Anim. Sci. 72:3066-3072.

Blasco, A., J. A. Ortega, A. Climent, and M. A. Santacreu. 2005. Divergent selection for uterine capacity in rabbits. I. Genetic parameters and response to selection. J. Anim. Sci. 83:2297-2302.

Boshier D. P.. 1969. A histological and histochemical examination of implantation and early placentome formation in sheep. J. Reprod. Fertil. 19(1):51-61.

Boshier D. P., R. J. Fairclough, and H. Holloway. 1987. Assessment of sheep blastocyst effects on neutral lipids in the uterine caruncular epithelium. J. Reprod. Fertil. 79:569-573.

Bott, R. C., R. Ashley, L. E. Henkes, A. Q. Antoniazzi, J. Bruemmer, N. P. Smirnova, R. V. Anthony, G. D. Niswender, F. W. Bazer, T. E. Spencer, and T. R. Hansen. 2009. Uterine vein infusion of interferon tau (IFNT) stimulates luteal gene expression, prevents anti-steroidogenic actions of prostaglandin F2alpha (PGF) and extends luteal lifespan in ewes. (Supplement) Biol Reprod. 81:577.

Bott, R. C., R. Ashley, L. E. Henkes, J. Bruemmer, G. D. Niswender, T. E. Spencer, F. W. Bazer, R. V. Anthony, and T. R. Hansen. 2008. Uterine vein infusion of interferon-tau acts systemically to induce ISG15 in the ovine corpus luteum. (Abstract) Bio. Reprod. 78:636.

Boujenane, I., G. E. Bradford, and T. R. Famula. 1991. Inheritance of litter size and its components in crosses between the D'man and Sardi breeds of sheep. J. Anim. Sci. 69: 517-524.

Bradford, G. E., A. Lahlou-Kassi, Y.M. Berger, I. Boujenane, and L. Derqaoui. 1989. Performance of D'man and Sardi sheep on accelerated lambing II. Ovulation rate and embryo survival. Small Ruminant Research 2:241-252.

Bradford, G. E., J. F. Quirke, and T. R. Famula. 1986a. Fertility, embryo survival and litter size in lines of Targhee sheep selected for weaning weight or litter size. J. Anim. Sci. 62:895-904. 
Bradford, G. E., J. F. Quirke, P. Sitorus, Ismeth Inounu, Bess Tiesnamurti, F. L. Bell, I. C. Fletcher, and D. T. Torell. 1986b. Reproduction in Javanese sheep: evidence for a gene with large effect on ovulation rate and litter size. J. Anim. Sci. 63:418-431.

Bremer, Jennifer. New genetic defect affects Angus cattle. High plains/Midwest Ag Journal. 6 Star Midwest Ag/1-B 11/17/08 article 2008- 47 - NewgeneticdefectaffectsAngu.cfm.

Breuel, K. F., P. E. Lewis, F. N. Schrick, A. W. Lishman, E. K. Inskeep, and R. L. Butcher. 1993. Factors affecting fertility in the postpartum cow: role of the oocyte and follicle in conception rate. Biol. Reprod. 48:655-661.

Bridges, P. J., and J. E. Fortune. 2003. Characteristics of developing prolonged dominant follicles in cattle. Dom. Anim. Endocrinol. 25:199-214.

Buckrell, B. C. 1988. Applications of ultrasonography in reproduction in sheep and goats. Theriogenology 29:71-84.

Buckrell, B. C., B. N. Bonnett, and W. H. Johnson. 1986. The use of real-time ultrasound rectally for early pregnancy diagnosis in sheep. Theriogenology 29:71-84.

Burghardt, R. C., G. A. Johnson, L. A. Jaeger, H. Ka, J. E. Garlow, T. E. Spencer, and F. W. Bazer. 2002. Integrins and extracellular matrix proteins at the maternal-fetal interface in domestic animals. Cells Tissues Organs 171:202-217.

Burghardt, R. C., J. A. Bowen, G. R. Newton, and F. W. Bazer. 1997. Extracellular matrix and the implantation cascade in pigs. J. Reprod. Fertil. Suppl. 52:151-164.

Carr, A. L., W. C. Russell, R. H. Stobart, P. Bulgin, and G. E. Moss. 2001. Is there an influence of individual rams on ewe prolificacy in sheep and goats? Sheep and Goat Res. J. 17:27-28.

Carr, A. L., W. C. Russell, R. H. Stobart, F. S. Hruby, P. Bulgin, and G.E. Moss. 2000. Influence of individual rams on ewe prolificacy. American Society of Animal Science Western Section abst. 134.

Carson, D. D., I. Bagchi, S. K. Dey, A. C. Enders, A. T. Fazleabas, B. A. Lessey, and K. Yoshinaga. 2000. Embryo implantation. Dev. Biol. 223(2):217-237.

Cassell, B. G., V. Adamec, and R. E. Pearson. 2003. Effect of incomplete pedigrees on estimates of inbreeding and inbreeding depression for days to first service and summit milk yield in Holsteins and Jerseys. J. Dairy Sci. 86: 2967-2976.

Charpigny, G., P. Reinaud, J. P. Tamby, C. Creminon, and M. Guillomot. 1997a. Cyclooxygenase-2 unlike cyclooxygenase-1 is highly expressed in ovine embryos during the implantation period. Biol. Reprod. 57:1032-1040. 
Charpigny, G., P. Reinaud, J.P Tamby, C. Creminon, J. Martal, and J. Maclouf. 1997b.

Expression of cyclooxygenase- 1 and -2 in ovine endometrium during the estrous cycle and early pregnancy. Endocrinology. 138:2163-2171.

Chemineau, P., D. Guillaume, M. Migaud, J. C. Thiéry, M. T. Pellicer-Rubio, and B. Malpaux. 2008. Seasonality of reproduction in mammals: intimate regulatory mechanisms and practical implications. Reprod. Dom. Anim. Suppl. 2. 43:40-47.

Courot, M. 1967. Endocrine control of the supporting and germ cells of the impubertal testis. Journal of Reproduction and Fertility ( supplement 2) 89- 101.

Courot, M., M. Hochereau-de Reviers, C. Monet-Kuntz, A. Locatelli, C. Pisselet, M. R. Blanc, and J. L. Dacheux. 1979. Endocrinology of spermatogenesis in the hypophysectomized ram. Journal of Reproduction and Fertility ( Supplement) 26:165-173.

Crim, L. W. and I. I. Geschwind. 1972a. Testosterone concentration in spermatic vein plasma of the developing ram. Biology of Reproduction 7:42-46.

Cross, J. C.. 2000. Genetic insights into trophoblast differentiation and placental morphogenesis. Seminars Cell and Developmental Biology. 11:105-112.

Cross, J. C.. 2001. Genes regulating embryonic and fetal survival. Theriogenology 55:(1)193207.

Danke, Richard J., J. Roger, Panciera, and Allen D. Tillman. 1965. Gossypol toxicity studies with sheep. J. Anim. Sci. 24:1199-1201.

Davis, G. H. 2004. Fecundity genes in sheep. Anim. Reprod. Sci. 82-83:247-253.

Davis, G. H. 2005. Major genes affecting ovulation rate in sheep. Genet. Sci. Evol. (Suppl. 1) 37:S11-S23.

Davis G. H., K. G. Dodds, R. Wheeler, and N. P. Jay. 2001. Evidence that an imprinted gene on the X chromosome increases ovulation rate in sheep. Biol. Reprod. 64:216-221.

Davis, G.H., J.C. McEwan, P.F. Fennessy, K.G. Dodds, and P.A. Farquhar, 1991. Evidence for the presence of a major gene influencing ovulation rate on the Xchromosome on sheep. Biol. Reprod. 44:620-624.

Davis, G.H., G.W. Montgomery, A.J. Allison, R.W. Kelly, and A.R. Bray. 1982. Segregation of a major gene influencing fecundity in progeny of Booroola sheep. N.Z. J. Agric. Res. $25: 525-$ 529.

Deas, D. W. 1977. Pregnancy diagnosis in the ewe by an ultrasonic rectal probe. Vet. Rec. 101:113-115. 
Delgadillo, J. A., B. Leboeuf, and P. Chemineau. 1992. Abolition of seasonal variations in semen quality and maintenance of sperm fertilizing ability by short photoperiodic cycles in he-goats.

Small Ruminant Res. 9:47-59.

Desjardins, C. 1978. Endocrine regulation of reproductive development and function in the male. Journal of Animal Science (Supplement 2) 47: 56-79.

Desjardins, C. 1981. Endocrine signaling and male reproduction. Biology of Reproduction 24:121.

Devonish, E. H., M. Knights, and E. K. Inskeep. 2009. Effect of expected peripheral concentrations of progesterone on ovulation rate and litter size in Barbados Blackbelly ewes. Sheep and Goat Research Journal. 24:17-25.

Diskin, M.G., J.J. Murphy, and J.M. Sreenan. 2006. Embryo survival in dairy cows managed under pastoral conditions. Anim Reprod Sci 96(3-4):297-311.

Diskin, M. G., and G. D. Niswender. 1989. Effect of progesterone supplementation on pregnancy and embryo survival in ewes. J. Anim. Sci. 67(6):1559-1563.

Dixon, A. B., M. Knights, J. L. Winkler, D. J. Marsh, J. L. Pate, M. E. Wilson, R. A. Dailey, G. Seidel, and E. K. Inskeep. 2007. Pattern of late embryonic and fetal mortality and association with several factors in sheep. J. Anim. Sci. 85:1274-1284.

Dixon, A.B. 2007. Late embryonic and fetal mortality in the ewe. Dissertation. West Virginia University.

Dutt, R. I I . and P. T. Hamm. 1957. Effect of exposure to high environmental temperature and shearing on semen production of rams in winter. J. Anim. Sci. 1 6:328.

Echternkamp, S. E. and D. D. Lunstra. 1984. Relationship between LH and testicular development in progesterone-implanted prepubertal ram lambs. J. Anim. Sci. 59:441-453.

Edwards, J. L., and P. J. Hansen. 1997. Differential responses of bovine oocytes and preimplantation embryos to heat shock. Mol. Reprod. Dev. 46:138-145.

Evans, A.C., J. D. Flynn, K. M. Quinn, P. Daffy, P. Quinn, S. Madgwick, T. F. Crosby, M. P. Bolan, and A. P. Beard. 2001. Ovulation of aged follicles does not affect embryo quality or fertility after a 14-day progestagen estrus synchronization protocol in ewes. Theriogenology 56(5):923-36.

Everett-Hincks, J. M., and K. G. Dodds. 2008. Management of maternal-offspring behavior to improve lamb survival in easy care sheep systems. J. Anim. Sci. 86:E259-E270. 
Faris, B. R., T. T. Ross, A. S. Carman, C. H. Martinez, B. J. Herron, J. R. Saenz, and D. M. Hallford. 2004. Effects of progesterone therapy on embryonic survival and pregnancy rates in ewes. Proceedings, Western Section, American Society of Animal Science. 55:312-314.

Ferris, H. A., and M. A. Shupnik. 2006. Mechanisms for pulsatile regulation of the gonadotropin subunit genes by GNRH1. Biol. Reprod. 74:993-998.

Flèchon J. E., M. Guillomot, M. Charlier, B. Flechon, and J. Martal. 1986. Experimental studies on the elongation of the ewe blastocyst. Reprod. Nutr. Dev. 26:1017-1024.

Palermo, G. D., L.T. Colombero, and Z. Rosenwaks. 1997. The human sperm centrosome is responsible for normal syngamy and early embryonic development. Rev. Reprod. 2:19-27.

Gearheart, M. A., W. E. Wingfield, A. P. Knight, J. A. Smith, D. A. Dargatz, J. A. Boon, and C. A. Stokes. 1988. Real-time ultrasonography for determining pregnancy status and viable fetal numbers in ewes. Theriogenology 30:323-377.

Geisert, R. D., G. L. Morgan, E. C. Short Jr., and M. T. Zavy. 1992. Endocrine events associated with endometrial function and conceptus development in cattle. Reprod. Fertil. Dev. 4(3):301305.

Ginther, O. J. 1983. Mobility of the early equine conceptus Theriogenology 19(4):603-611.

Ginther, O. J. 1995 Ultrasonic imaging and animal reproduction. Cross Plains, WI: Equiservices Publishing.

Goodman, R. L., and E. K. Inskeep. 2006. Neuroendocrine control of the ovarian cycle of the sheep. In: Neill, Jimmy D. (Ed.), Knobil and Neill's Physiology of Reproduction, Third Edition. Raven Press, New York, New York.

Gray, C. A., F. F. Bartol, K. M. Taylor, A. A. Wiley, and W. S. Ramsey. 2000. Ovine uterine gland knock-out model: effects of gland ablation on the estrous cycle. Biol. Reprod. 62:448-456.

Gray, C. A., K. M. Taylor, W. S. Ramsey, J. R. Hill, F. W. Bazer, F. F. Bartol, and T. E. Spencer. 2001. Endometrial glands are required for preimplantation conceptus elongation and survival. Biol. Reprod. 64(6):1608-1613.

Griffin, P. G., and O. J. Ginther. 1992. Research applications of ultrasonic imaging in reproductive biology. J. Anim. Sci. 70:953-972.

Guillomot M. 1995. Cellular interactions during implantation in domestic ruminants. Journal of Reproduction and Fertility Supplement. 49:39-51.

Guillomot, M., J. E. Flechon, and S. Winterberger-Torres. 1981. Conceptus attachment in the ewe: an ultrastructural study. Placenta 2:169-182. 
Guillomot, M., and P. Guay. 1982. Ultrastructural features of the cell surfaces of uterine and trophoblastic epithelia during embryo attachment in the cow. Anat. Rec. 204:315-322.

Gustavsson, I. 1979. Distribution and effects of the 1/29 Robertsonian translocation in cattle. J. Dairy Sci. 62:825-835.

Haranahan, J. P. 1976. Repeatability of ovulation rate and its relationship with litter size in four sheep breeds. Proc. 27th Ann. Meeting E.A.A.P. (Zurich), G30:1-8.

Hanrahan, J. P. 1982. Selection for increases ovulation rate, litter size and embryo survival. Proc. 2nd World Congr. Genet. Appl. Livest. Prod. 5:294-309.

Hanrahan, J. P. 1994. Embryo survival in small ruminants: incidence and sources of variation. In: 45th Annual Meeting European Association of Animal Production, Edinburgh, Sheep and Goat Commission, Session 2.

Hanrahan, J. P., and L. R. Piper. 1992. Nature of the genetic control of ovulation rate and its relationship with litter size. In: Proceedings of 30th Annual Meeting E.A.A.P., Leningrad, GS4.2:12.

Hansen, L. B. 2000. Consequences of selection for milk yield from a geneticist's viewpoint. J. Dairy Sci. 83:1145-1150.

Hansen, P. J., M. Drost, R. M. Rivera, F. F. Paula-Lopes, Y. M. Al-Katanani, C. E. Krininger III, and C. C. Chase Jr.. 2001. Adverse impact of heat stress on embryo production: Causes and strategies for mitigation. Theriogenology 55:91-103.

Hansen, T. R., K.J. Austin, D. J. Perry, J. K. Pru, M. G. Teixeira, and G. A. Johnson. 1999. Mechanism of action of interferon-tau in the uterus during early pregnancy. J. Reprod. Fertil. 54(Suppl):329-339.

Hendy, C. R. C, and J. C. Bowman. 1974. The association between variation in the seasonal onset of estrus and litter size in the ewe. J. Reprod. Fertil. 40:105-112.

Henning, W. L. 1939. Prenatal and postnatal sex ratio in sheep. J. Agric. Res. 58:565-579.

Hesselink, J. W., and M. A. M. Taverne. 1994. Ultrasonography of the uterus of the goat. Vet. Q. $16: 41-45$.

Hixon, J. E., and A. P. Flint. 1987. Effects of a luteolytic dose of oestradiol benzoate on uterine oxytocin receptor concentrations, phosphoinositide turnover and prostaglandin F-2 alpha secretion in sheep. J. Reprod. Fertil. 79:457-467.

Hochereau-de Reviers, M. T. 1976. Variation in the stock of testicular stem cells and in the yield of spermatogonial divisions in ram and bull testes. Andrologia 8:(2)137-146. 
Hooper, S. B., W. B. Watkins, and G. D. Thorburn. 1986. Oxytocin, oxytocin-associated neurophysin, and prostaglandin $\mathrm{F}_{2}$ alpha concentrations in the utero-ovarian vein of pregnant and nonpregnant sheep. Endocrinology 119:2590-2597.

Horvarth, M., K. Mottle, and L. Szabo. 1978. Early diagnosis of pregnancy in sheep by the ultrasonic Doppler method. Anim. Breed. Abstr. 47:320.

Howarth, B. Jr. 1969. Fertility in the ram following exposure to elevated ambient temperature and humidity. J. Reprod. Fertil. 19:179.

Hulet, C. V., W. C. Foote, and R. L. Blackwell. 1965. Relationship of semen quality and fertility in the ram to fecundity in the ewe. J. Reprod. Fertil. 9: 311-315.

Hulet, C. V., H. P. Voightlander, A. L. Pope, and L. E. Casida. 1956. The nature of early-season infertility in sheep. J. Anim. Sci. 15:607-616.

Humblot, P. 2001. Use of pregnancy specific proteins and progesterone assays to monitor pregnancy and determine the timing, frequencies and sources of embryonic mortality in ruminants. Theriogenology 56:1417-1433.

Humblot, P., and J. B. Denis. 1986. Sire effects on cow fertility and late embryonic mortality in the montbeliard breed. Livest. Prod. Sci. 14(2):139-148.

Hutchenson, L. R. 1962. The hemodynamics of the isolated pregnant uterus of the cow (Bos tarus). M.S. Thesis. Iowa State University, Ames.

Inskeep, E. K. 1995. Factors that affect fertility during estrous cycles with short and normal luteal phases in postpartum cattle. J. Reprod. Fertil. (Suppl. 49):493-503.

Inskeep, E. K., A. L. Barr, and C. J. Cunningham. 1967. Repeatability of Prolificacy in Sheep. J. Anim. Sci. 26:458-461.

Jackson, N. S., W. J. Greer, and J. K. Baker. 2000. Animal Health. (3rd ed.) Danville, Illinois: Interstate Publishers, Inc.

James, L. F., K. E. Panter, D. B. Nielsen, and R. J. Molyneux. 1992. The effect of natural toxins on reproduction in livestock. J. Anim. Sci. 70:1573-1579.

Johnson, G. A., F. W. Bazer, L. A. Jaeger, H. Ka, J. E. Garlow, C. Pfarrer, T. E. Spencer, and R. C. Burghardt. 2001. Muc-1, integrin, and osteopontin expression during the implantation cascade in sheep. Biol. Reprod. 65(3):820-828.

Johnson, S. K., R. A. Dailey, E. K. Inskeep, and P. E. Lewis. 1996. Effect of peripheralconcentrations of progesterone on follicular growth and fertility in ewes. Domest. Anim. Endocrinol. 13:69-79. 
Kastelic, J. P., D. L. Northey, and O. J. Ginther. 1991. Spontaneous embryonic death on days 20 to 40 in heifers. Theriogenology 35:351-363.

Kieborz-Loos, K. R., H. A. Garverick, D. H. Keisler, S. A. Hamilton, B. E. Salfen, R. S. Youngquist, M. F. Smith. 2003. Oxytocin-induced secretion of prostaglandin F2 \{alpha\} in postpartum beef cows: Effects of progesterone and estradiol-17\{beta $\}$ treatment. J. Anim Sci. 81:1830-1836.

King G. J., B. A. Atkinson, and H. A. Robertson. 1980. Development of the bovine placentome from days 20 to 29 of gestation. J. Reprod. Fertil. 59(1):95-100.

Kleemann, D.O., S.K. Walker, J.R.W. Walkley, D.H. Smith, R.W. Ponzoni, and R.F. Seamark. 1990. Factors influencing lamb survival in a high fecundity Booroola Merino $\times$ South Australian Merino flock. Theriogenology 33(5):965-976.

Knights, M., Q. S. Baptiste, A. B. Dixon, J. L. Pate, E. K. Inskeep, and P. E. Lewis. 2003. Effect of dosage of follicle stimulating hormone (FSH), vehicle and time of injection on ovulation rate and prolificacy in anestrous ewes. Sm. Rum. Res. 50(1):1-9.

Knights, M., T. Hoehn, P. E. Lewis, and E. K. Inskeep. 2001a. Effectiveness of intravaginal progesterone inserts and FSH for inducing synchronized estrus and increasing lambing rate in anestrous ewes. J. Anim. Sci. 79: 1120-1131.

Knights, Marlon, Todd Hoehn, Deborah Marsh, Paul Lewis, Joy Pate, Alison Dixon, and Keith Inskeep. 2003. "Reproductive management in the ewe flock by induction or synchronization of estrus". (West Virginia Agri. For Exp. Sta. Bul. 726), Morgantown, West Virginia.

Knights, M., T. D. Maze, P. J. Bridges, P. E. Lewis, and E. K. Inskeep. 2001b. Shortterm treatment with a controlled internal drug releasing (CIDR) device and FSH to induce fertile estrus and increase prolificacy in anestrus ewes. Theriogenology 55:1181-1191.

Kramer, R. Y., D. L. Garner, S. A. Erisson, D. A. Wesen, T. W. Downing, and D. Redilman. 1991. The effect of cottonseed component on testicular development in pubescent rams. Vet. Hum. Toxicol. 33:11.

Kusina, N. T., R. L. Meyer, K. M. Carlson, and J. E. Wheaton, 1995. Passive immunization of ewes against an inhibin-like peptide increases follicle-stimulating hormone concentrations, ovulation rate, and prolificacy in spring-mated ewes. J. Anim. Sci. 73:1433-1439.

Lee, R. S., T. T. Wheeler, and A. J. Peterson. 1998. Large-format, two-dimensional polyacrylamide gel electrophoresis of ovine periimplantation uterine luminal fluid proteins: identification of aldose reductase, cytoplasmic actin, and transferrin as conceptus- synthesized proteins. Biol. Reprod. 59(4):743-752.

Lessey, B. A. 1998. Endometrial integrins and the establishment of uterine receptivity. Human Reprod. 13 Suppl 3:247-258. 
Lessey, B. A. 2002. Adhesion molecules and implantation. J. Reprod. Immunol. 55(1-2):101112.

Leung, S. T., K. Derecka, G. E. Mann, A. P. F. Flint, and D. C. Wathes. 2000. Uterine lymphocyte distribution and interleukin expression during early pregnancy in cows. J. Reprod. Fertil. 119:25-33.

Lincoln, G. A. 1979. Photoperiodic control of seasonal breeding in the ram: Participation of the cranial sympathetic nervous system. J. Endocrinology 82:135-147.

Lindahl, I. L. 1971. Pregnancy diagnosis in the ewe by intrarectal Doppler. J. Anim. Sci. 32:922925.

López-Gatius, F., R. H. F. Hunter, J. M. Garbayo, P. Santolaria, J. Yániz, , B. Serrano, A. Ayad, N. M. de Sousa, and J. F. Beckers. 2007. Plasma concentrations of pregnancy-associated glycoprotein-1 (PAG-1) in high producing dairy cows suffering early fetal loss during the warm season. Theriogenology 67:1324-1330.

López-Gatius, F., Santolaria, P., Yániz, J., Rutllant, J., López-Béjar, M., 2002. Factors affecting pregnancy loss from gestation day 38 to 90 in lactating dairy cows from a single herd. Anim. Reprod. Sci. 57, 1251-1261.

Lunstra, D. D., and R. K. Chirstensen. 1981. Synchronization of ewes during anestrus: influence of time of year and interval to onset of estrus on conception rate. J. Anim. Sci. 53:448-457.

Malher, X., F. Beaudeau, and J.M. Philipot. 2006. Effects of sire and dam genotype for complex vertebral malformation (CVM) on risk of return-to-service in Holstein dairy cows and heifers. Theriogenology 65:1215-1225.

Mankey, J. E.. Effects of the oxytocin receptor blocker, atosiban, on function of ovine corpora lutea and responses to prostaglandin F2 alpha. 2009. Thesis. West Virginia University.

Mann, G. E., and G. E. Lamming. 2001. Relationship between maternal endocrine environment, early embryo development and inhibition of the luteolytic mechanism in cows. Reproduction 121:175-180.

Martal, J., N. Chene, S. Camous, L. Huynh, F. Lantier, P. Hermier, R. L'Haridon, G. Charpigny, M. Charlier, and G. Chaouat. 1997. Recent developments and potentialities for reducing embryo mortality in ruminants: the role of IFN-tau and other cytokines in early pregnancy. Reprod. Fertil. Dev. 9(3):355-380.

Maurer, R. R., and J. R. Chenault. 1983. Fertilization failure and embryonic mortality in parous and nonporous beef cattle. J. of Anim. Sci. 56:1186-1189. 
McCarthy, M. S., H. D. Hafs, and E. M. Coney. 1979b. Serum hormone patterns associated with growth and sexual development in bulls. Journal of Animal Science 49:1012-1020.

McCracken, J. A., D. T. Baird, and J. R. Goding. 1971. Factors affecting the secretion of steroids from the transplanted ovary in the sheep. Recent Prog. Horm. Res 27:537-582.

McCracken, J. A., E. E. Custer, and J. C. Lamsa. 1999. Luteolysis: a neuroendocrinemediated event. Physiol. Rev. 79:263-323.

McCracken, J. A., W. Schramm, and W. C. Okulicz. 1984. Hormone receptor control of pulsatile secretion of PGF-2alpha from the ovine uterus during luteolysis and its abrogation in early pregnancy. Anim. Reprod. Sci. 7:31-55.

McMillan, W. H., and M. F. McDonald. 1985. Survival of fertilized ova from ewe lambs and adult ewes in the uteri of ewe lambs. Anim. Reprod. Sci. 8:235-240.

Meyer, H. H. 1985. Breed differences in ovulation rate and uterine efficiency and their contribution to fecundity. In: Genetics of Reproduction in Sheep. R. B. Land, and D. W. Robinson, eds. Buttersworth, London.

Meyer, H. H. 2002. Genetic and Environmental Impacts on Prenatal Lamb Loss. Sheep and Goat research Journal. 17, No. 3 Special Issue.

Meyer, H. H., and K. S. West. 1991. Genetic variation in embryo survival in sheep. Wool Technology and Sheep Breeding 39:75-77.

Mihm, M., A. Baguisi, M. P. Boland, and J. F. Roche. 1994. Association between the duration of dominace of the ovulatory follicle and pregnancy rate in beef heifers. J. Reprod. Fertil. 102:123130.

Mihm, M., N. Curran, P. Hyttel, P. G. Knight, M. P. Boland, and J. F. Roche. Effect of dominant follicle persistence on follicular fluid oestradiol and inhibin and on oocyte maturation in heifers. J. Reprod. Fertil. 116: 293-304.

Mitchell, L. M., M. E. King, R. P. Aitken, F. E. Gebbie and J. M. Wallace. 1999. Ovulation, fertilization and lambing rates, and peripheral progesterone concentrations, in ewes inseminated at a natural oestrus during November or February. J. Reprod. Fertil. 115:133-140.

Mitchell, L. M., M. E. King, R. P. Aitken, and J. M. Wallace. 1996. Effect of mating season and body condition on ovulation, fertilization and pregnancy rates in crossbred ewes. Theriogenology 45:293.

Moce, M. L., M. A. Santacreu, A. Climent, and A. Blasco. 2005. Divergent selection for uterine capacity in rabbits. III. Responses in uterine capacity and its components estimated with a cryopreserved control population. J. Anim. Sci. 83:2308-2312. 
Morris, L. H., A. E. Randall, W. A. King, W. H. Johnson, and B. C. Buckrell. 2003. The contribution of the male to ovine embryogenesis in an in vitro embryo production system. Anim. Reprod. Sci. 15:75(1-2)9-26.

Mullaney, P D., G. H. Brown. 1969. The influence of age on reproductive performance on sheep in Australia. Australian Journal of Agriculture Research 20(5) 953-963.

Murdoch, W. J., and E. A. Van Kirk. 1998. Luteal dysfunction in ewes induced to ovulate early in the follicular phase. Endocrinology 139:3480-3484.

Murray, M. K. 1993. An estrogen-dependent glycoprotein is synthesized and released from the oviduct in a temporal- and region-specific manner during early pregnancy in the ewe. Biol. Reprod. 48:446-453.

Mussard, M. L., C. R. Burke, C. L. Gasser, E. J. Behlke, K. A. Colliflower, D. E. Grum, and M. L. Day. 2003. Ovulatory response, luteal function and fertility in cattle induced to ovulate dominant follicles of early or late maturity. Biol Reprod. 68(1):332 (Abstr. 535).

Nawaz, M., and H. H. Meyer. 1991. Effects of genotype and mating weight on ovulation rate, litter size, and uterine efficiency of Coopworth, Polypay, and crossbred ewes. J. Anim. Sci. 69:3925-3930.

Nielsen, U. S., G. P. Aamand, O. Andersen, C. Bendixen, V. H. Nielsen, and J. S. Agerholm. 2003. Effects of complex vertebral malformation on fertility traits in Holstein cattle. Livestock Production Sci. 79:233-238.

Nino-Soto, M. I., and W. A. King. 2004. Genetic factors that affect normal reproduction and fertility in domestic cattle. Proc. 23rd World Buiatrics Congress, Quebec, Canada. http://www.ivis.org/ proceedings/wbc/wbc2004/WBC2004-NinoSoto-simple.pdf.

Niswender, G. D., T. L. Davis, R. H. Griffith, R. L. Bogan, K. Monser, R. C. Bott, J. E. Bruemmer, and T. M. Nett. Judge, jury, and executioner: the auto-regulation of luteal function. Society of Reproduction and Fertility Supplement. 2007. 64: 191-206.

O'Callaghan, D., H. Yaakub, P. Hyttel, L. J. Spicer, and M. P. Boland, 2000. Effect of nutrition and superovulation on oocyte morphology, follicular fluid composition and systemic hormone concentrations in ewes. Journal of Reproduction and Fertility, 118: 303-313.

Ortavant, R., J. Pelletier, J. P. Ravault, J. Thimonier, and P. Volland. 1985. Photoperiod: main proximal and distal factor of the circannual cycle of reproduction in farm mammals. Oxford Rev. Reprod. Biol. 7:305-345.

Padilla-Rivas, G. R., B. Sohnery, W. Holtz. 2005. Early pregnancy detection by real-time ultrasonography in Boer goats. Small Rumin. Res.. 58:87-92. 
Palermo, G. D., L. T. Colombero, and Z. Rosenwaks. 1997. The human sperm centrosome is responsible for normal syngamy and early embryonic development. Review of Reproduction 2: $19-27$.

Palermo, G. D., S. Munne, and J. Cohen. 1994. The human zygote inherits its mitotic potential from the male gamete. Human Reproduction 9:1220-1225.

Panter, K. E., T. D. Bunch, L. F. James, and D. C. Sisson. 1987. Ultrasonographic imaging to monitor fetal and placental developments in ewes fed locoweed (Astragalus lentiginosus). Am. J. Vet. Res. 48:688

Pegorer, M. F., J. L. M. Vasconcelos, L. A. Trinca, P. J. Hansen, and C. M. Barros. 2007. Influence of sire and sire breed (Gyr vs. Holstein) on establishment of pregnancy and embryonic loss in lactating Holstein cows during summer heat stress. Theriogenology 67:692-697.

Peiro, R., M. A. Santacreu, A. Climent, and A. Blasco. 2007. Early embryonic survival and embryo development in two lines of rabbits divergently selected for uterine capacity. J. Anim. Sci. 85:1634-1639.

Perry, G. A., M. F. Smith, M. C. Lucy, A. J. Roberts, M. D. MacNeil, and T. W. Geary. 2003a. Effect of ovulatory follicle size at time of GnRH injection or standing estrus on pregnancy rates and embryonic/fetal mortality in beef cattle. Proc. Western Sec., Amer. Soc. Anim. Sci. 54.

Perry, G. A., M. F. Smith, A. J. Roberts, M. D. MacNeil, and T. W. Geary. 2003b. Effect of ovulatory follicle size at time of GnRH injection on preovulatory serum concentrations of estradiol in beef cows detected or not detected in standing estrus. Biol. Reprod. 68(1):330 (Abstr. 530).

Peters, M. W., and J. R. Pursley. 2003. Timing of final GnRH of the ovysynch protocol affects ovulatory follicle size, subsequent luteal function, and fertility in dairy cows. Theriogenology 60:1197-1204.

Pierson, R. A., and G. P. Adams. 1995. Computer-assisted image analysis, diagnostic ultrasonography and ovulation induction: strange bedfellows. Theriogenology 43:105-112.

Pierson, R.A, J.P. Kastelic, and O.J. Ginther. 1988. Basic principles and techniques for transrectal ultrasonography in cattle and horses. Theriogenology 29:3-20.

Quirke, J. F., and J. P. Hanrahan. 1977. Comparison of the survival in the uteri of adult ewes of cleaved ova from adult ewes and ewe lambs. J. Reprod. Fertil. 51:487-489.

Quirke, J. F., and J. P. Hanrahan. 1983. Comparison of the survival of fertilized eggs from adult ewes in the uteri of adult ewes and ewe lambs. J. Reprod. Fertil. 68:289-294.

Radomska, J. H., E. Martyniuk, J. Klewiek, and A. Knothe. 1988. Inheritance of high prolificacy of the Olkuska sheep (preliminary results). J. Agric. Sci. Fin. 60:418-431. 
Restall, B. J., G. H. Brown, MdeB. Blickey, L. Cahill, and R. Kearns. 1976. Assessment of reproductive wastage in sheep. 1. Fertilization failure and early embryonic survival. Aust. J. Exp. Agric. Anim. Husb. 16:329-335.

Revah, I., and W. R. Butler. 1996. Prolonged dominance of follicles and reduced viability of bovine oocytes. J. Reprod. Fertil. 106:39-47.

Rhind, S. M., W. A. C. McKelvey, S. R. McMillian, R. G. Gunn, and D. A. Elston. 1989. Effect of restricted food intake before and / or after mating, on the reproductive performance of Greyface ewes. Anim. Prod. 48:149-155.

Rhind, S. M., J. J. Robinson, C. Fraser, and I McHattie. 1980b. Ovulation and embryo survival rates and plasma progesterone concentrations of prolific ewes treated with PMSG. J. Reprod. Fertil. 58:139-144.

Rhind, S. M., J. J. Robinson, and I. McDonald. 1980a. Relationships among uterine and placental factors in prolific ewes and their relevance to variations in fetal weight. Anim. Prod. 30:115-124.

Ricordeau, G., J. P. Poivey, L. Bodin, F. Barillet and M. Roussely. 1986. Importance of testicular measurements of young males tested on individual performance for improvement of their daughters' prolificacy: application to the selection scheme on the Lacaune milking breed. Proc. 3rd World Congr. on Genet. AppI. Livest. Prod. 11:72.

Roberts, J.S., J. A. McCracken, J. E. Gavagan, and M. S. Soloff. Oxytocin-stimulated release of prostaglandin F2 $\alpha$ from ovine endometrium in vitro: Correlation with estrus cycle and oxytocin receptor binding. Endocrinology. 1976; 99:1107-1114.

Roberts, R. M., and F. W. Bazer. 1988. The functions of uterine secretions. J. Reprod. Fertil. 82(2):875-892.

Roberts, R. M., J. C. Cross, and D. W. Leaman. 1992. Interferons as hormones of pregnancy. Endocronology Rev. 13:432-452.

Roberts, R. M., T. Ezashi, C. S. Rosenfeld, A. D. Ealy, and H. M. Kubisch. 2003. Evolution of the interferon tau genes and their promoters, and maternal-trophoblast interactions in control of their expression. Reprod. Suppl. 61:239-251.

Roberts, R. M., T. Schalue-Francis, H. Francis, and D. Keisler. 1990. Maternal recognition of pregnancy and embryonic loss. Theriogenology 33:175-183.

Roberts, R. M., S. Xie, and N. Mathialagan. 1996. Maternal recognition of pregnancy. Biol. Reprod. 54, 294-302.

Robinson, T. J. 1951. The control of fertility in sheep. Part II. The augmentation of fertility by gonadotrophin treatment of the ewe in the normal breeding season. J. Agric. Sci. Camb. 41:6-63. 
Rosenfeld, C. R., F. H. Morriss, Jr., E. L. Makowski, G. Meschia, and F. C. Battaglia. 1974. Circulatory changes in the reproductive tissues of ewes during pregnancy. Gynecol. Invest. $5: 252-268$.

Santos, J. E. P., W. W. Thatcher, R. C. Chebel, R. L. A. Cerri, and K. N. Galvao. 2004. The effect of embryonic death rates in cattle on the efficacy of estrus synchronization programs. Anim. Reprod. Sci. 83:513-535.

Santos, J. E. P., M. Villasenor, E. J. DePeters, P. H. Robinson, C. H. Holmberg,. 2003. Type of cottonseed and level of gossypol in diets of lactating dairy cows: plasma gossypol, health, and reproductive performance. J. Anim. Sci. 86:892-905.

Saoud, N. B., D. L. Thomas, and W. D. Hohenboken. 1984. Breed and sire effects on crossbred lamb production from Panama ewes and on spermatozoan midpiece length. J. Anim. Sci. 59:2938 .

Schanbacher, B. D. 1982a. Hormonal interrelationships between hypothalamus, pituitary 243 and testis of rams and bulls. Journal of Animal Science, supplement 5556-5567.

Schanbacher, B. D. 1982b. Responses of ram lambs to active immunization against testosterone and luteinizing hormone-releasing hormone. American Journal of Physiology 242:E201-E2O5.

Schanbacher, B. D. 1984. Regulation of luteinizing hormone secretion in male sheep by endogenous estrogen. Endocrinology 115:944-950.

Schrick, F. N., and E. K. Inskeep. 1993. Determination of early pregnancy in ewes utilizing transrectal ultrasonography. Theriogenology 40:295-306.

Schrick, F. N., R. A. Surface, J. Y. Pritchard, R. A. Dailey, E. C. Townsend, and E. K. Inskeep. 1993. Ovarian structures during the estrous cycle and early pregnancy in ewes. Biol. Reprod. 49:1133-1140.

Senger, P. L. 2005. Early embryogenesis and maternal recognition of pregnancy. In Pathways to Pregnancy and Parturition. Current Conceptions, Inc. Pullman, WA.

Shanks, Roger D., and James L. Robinson. 1989. Embryonic mortality attributed to inherited deficiency of uridine monophosphate synthase. J. Dairy Sci. 72: 3035-3039.

Sharpe, R.M. 1990. Intratesticular control of steroidogenesis (review). Clinical Endocrinology 33:787-807.

Sheep Production Handbook (7th Ed). 2003. American Sheep Industry Association, Inc. Colorado, C\&M Press. 
Shelton, M., and J. E. Hutson. 1968. Effects of high temperature stress during gestation on certain aspects of reproduction in the ewe. J. Anim. Sci. 27:153-160.

Shirley, I. M. 1978. A User's Guide to Diagnostic Ultrasound. Baltimore, University Park Press. James S. T. Yao, MD, PhD, Reviewer Northwestern University Medical School Chicago JAMA. 1979;242(20):2235.

Sidwell, G. M., D. O. Everson, and C. E. Terrill. 1962. Fertility, prolificacy and lamb livability of some pure breeds and their crosses. J. Anim. Sci. 21:875-879.

Silke, V., M. G. Diskin, D. A. Kenny, M. P. Boland, P. Dillon, J. F. Mee, J. M. Sreenan. 2002. Extent, pattern and factors associated with late embryonic losses in dairy cows. Anim. Reprod. Sci. 71:1-12.

Silvia, P. J., J. L. Juengel, M. K. Rollyson, G. D. Niswender. 2000. Prostaglandin metabolism in the ovine corpus luteum: catabolism of prostaglandin $\mathrm{F}_{2} \alpha\left(\mathrm{PGF}_{2} \alpha\right)$ coincides with resistance of the corpus luteum to PGF2 $\alpha$. Biol. Reprod. 63:1229-1236.

Silvia, W. J., and R. E. Raw. 1993. Regulation of pulsatile secretion of prostaglandin $\mathrm{F}_{2}$ alpha from the ovine uterus by ovarian steroids. J. Reprod. Fertil. 98:341-347.

Simmen, R. C., and F. A. Simmen. 1990. Regulation of uterine and conceptus secretory activity in the pig. J. Reprod. Fertil. Suppl 40:279-292.

Skinner, M. K. 1991. Cell-cell interaction in the testis. Endocrine Reviews 12:45-77.

Skinner, J.D., W. D. Booth, L. Rowson, and H. Karg. 1968. The postnatal development of reprouctive tract of Suffolk ram, and changes in the gonadotrophin content of the pituitary. Journal of Reproduction and Fertility 16:463-477.

Southey, B. R., S. L. Rodriguez-Zas, and K. A. Leymaster. 2001. Survival analysis of lamb mortality in a terminal sire composite population. J. Anim. Sci. 79: 2298-2306.

Spencer, T. E., and F. W. Bazer. 1995. Temporal and spatial alterations in uterine estrogen receptor and progesterone receptor gene expression during the estrous cycle and early pregnancy in the ewe. Biol Reprod 53:1527-1543.

Spencer, T. E., and F. W. Bazer. 2004. Conceptus signals for establishment and maintenance of pregnancy. Reprod. Biol. Endocrinol. 2(1):49.

Spencer, T. E., F. W. Bazer. 1996. Ovine interferon tau suppresses transcription of the estrogen receptor and oxytocin receptor genes in the ovine endometrium. Endocrinology 137:1144-1147.

Spencer, T. E., and F. W. Bazer. 2002. Biology of progesterone action during pregnancy recognition and maintenance of pregnancy. Frontiers in Bioscience 7:d1879-1898. 
Spencer, T. E., and F. W. Bazer. 2004.Uterine and placental factors regulating conceptus growth in domestic animals. J. Anim. Sci. 82: 4-13.

Spencer, T. E., W. C. Becker, P. George, M. A. Mirando, T. F. Ogle, and F. W. Bazer. 1995a. Ovine interferon-tau inhibits estrogen receptor up-regulation and estrogeninduced luteolysis in cyclic ewes. Endocrinology 136:4932-4944.

Spencer, T. E., W. C. Becker, P. George, M. A. Mirando, T. F. Ogle, and F. W. Bazer. 1995b.Ovine interferon-tau regulates expression of endometrial receptors for estrogen and oxytocin but not progesterone. Biol. Reprod. 53:732-745.

Spencer, T. E., G. A. Johnson, F. W. Bazer, and R. C. Burghardt. 2004. Implantation mechanisms: insights from the sheep. Reproduction 128(6):657-668.

Spencer, T. E., G. A. Johnson, K. M. Taylor, and A. Gertler. 1999b. Effects of recombinant ovine interferon tau, placental lactogen, and growth hormone on the ovine uterus. Biol. Reprod. 61:1409-1418.

Spencer, T. E., A. G. Stagg, T. L. Ott, G. A. Johnson, W. S. Ramsey, F. W. Bazer. 1999a. Differential Effects of Intrauterine and Subcutaneous Administration of Recombinant Ovine Interferon Tau on the Endometrium of Cyclic Ewes. Biol Reprod. 61(2):464-470.

Stewart, M. D., G. A. Johnson, C. A. Gray, R. C. Burghardt, L. A. Schuler, M. M. Joyce, F. W. Bazer, and T. E. Spencer. 2000. Prolactin receptor and uterine milk protein expression in the ovine endometrium during the estrous cycle and pregnancy. Biol. Reprod. 62(6):1779-1789.

Stronge, A.J., J. M. Sreenan, M. G. Diskin, J. F. Mee, D. A. Kenny, and D. G. Morris. 2005. Post-insemination milk progesterone concentration and embryo survival in dairy cows. Theriogenology 64(5):1212-1224.

Thatcher, W. W., F. W. Bazer, D. C. Sharp, and R. M. Roberts. 1986. Interrelationship between uterus and conceptus to maintain corpus luteum function in early pregnancy: sheep, cattle, pigs, and horses. J Anim Sci. 62: 25-46.

Thatcher, W. W., K. L. Macmillan, P. J. Hansen, and M. Drost. 1989. Concepts for regulation of corpus luteum function by the conceptus and ovarian follicles to improve fertility. Theriogenology 31:149-164.

Thatcher,W.W., M.D. Meyer, and G. Danet-Desnoyers. (1995). Maternal recognition of pregnancy. J. Reprod. Fertil. Suppl 49, 15-28.

Van Cleeff, J., M. Drost, and W.W. Thatcher. 1991. Effects of postinsemination progesterone supplementation on fertility and subsequent estrous responses of dairy heifers. Theriogenology 36:795-807. 
Van Raden, P. M., C. M. B. Dematawewa, R. E. Pearson, and M. E. Tooker. 2006. Productive life including all lactations and longer lactations with diminishing credits. J. Dairy Sci. 89:3213.

Van Raden P. M., and R. H. Miller. 2006. Effects of nonadditive genetic interactions, inbreeding and recessive defects on embryo and fetal loss by seventy days. J. Dairy Sci. 89:2716-2721.

Vasconcelos, J. L. M., R. Sartori, H. N. Oliveira, J. G. Guenther, and M. C. Wiltbank. 2001. Reduction in size of the ovulatory follicle reduces subsequent luteal size and pregnancy rate. Theriogenology. 56:304-314.

Villaseñor, M., A. C. Coscioni, K. N. Galvão, R. C. Chebel, and J. E. Santos. 2008. Gossypol disrupts embryo development in heifers. J Dairy Sci. 91(8):3015-3024.

Viñoles, C., M. Forsberg, G. Banchero, and E. Rubianes. 2001. Effect of long-term and shortterm progestagen treatment on follicular development and pregnancy rate in cyclic ewes.

Theriogenology 55:993-1004.

Wallace, J. M., R. P. Aitken, and M. A. Cheyne. 1994. Effect of post-ovulation nutritional status in ewes on early conceptus survival and growth in vivo and luteotrophic protein secretion in vitro. Reproduction, Fertility and Development 6:253-259.

Wallace, J. M., D. A. Bourke, P. Da. Silva, and R. P. Aitken. 2003. Influence of progesterone supplementation during the first third of pregnancy on fetal and placental growth in overnourished adolescent ewes. Reproduction 126:481-487.

Wallace J.M., P. Da Silva, R. P. Aitken, and M. A. Cruickshank. 1997. Maternal endocrine status in relation to pregnancy outcome in rapidly growing adolescent sheep. Journal of Endocrinology 155:359-368.

Walton, J. S., J. D. Evins, M. A. Hillard and G. M. H. Waites. 1980. Follicle stimulating hormone in hemicastrated pre-pubertal rams and its relationship to testicular development. Journal of Endocrinology 84: 141 - 152.

Wathes D. C., and M. Hamon. 1993. Localization of oestradiol, progesterone and oxytocin receptors in the uterus during the oestrous cycle and early pregnancy of the ewe. Endocrinology 138:479-492.

Wathes D. C., and G. E. Lamming. 1995. The oxytocin receptor, luteolysis and the maintenance of pregnancy. J. Reprod. Fertil. Suppl. 49:53-67.

West, K. S., H. H. Meyer. and M. Nawaz. 1991. Effects of differential ewe condition at mating and early postmating nutrition on embryo survival. J. Anim. Sci. 69: 3931-3938.

Wilson, P. R. and K. R. Lapwood. 1979. Studies of reproductive development in Romney rams. 1. Basal levels and plasma profiles of LH, testosterone and prolactin. Biology of Reproduction 10:1278- 1284. 
Wiltbank, M. C., A. Gümen, and R. Sartori. 2002. Physiological classification of anovulatory conditions in cattle. Theriogenology 57:21-52.

Wimsatt W. A. 1950. New histological observations on the placenta of the sheep. Am. J. Anat. 87:391-436.

Wimsatt W. A. 1951. Observations on the morphogenesis, cytochemistry, and significance of the binocleate giant cells of the placenta of ruminants. Am. J. Anat. 89:233-281.

Wintenberger-Torres S., and J. E. Flechon. 1974. Ultrastructural evolution of the trophoblast cells of the pre-implantation sheep blastocyst from day 8 to day 18. J. Anat. 118:143-153.

Wooding, F. B.. 1984. Role of binucleate cells in fetomaternal cell fusion at implantation in the sheep. Am. J. Anat. 170(2):233-250.

Wooding, F. B.. 1992. Current topic: the synepitheliochorial placenta of ruminants: binucleate cell fusions and hormone production. Placenta 13:101-113.

Wooding, F. B., L. D. Staples, and M. A. Peacock. 1982. Structure of trophoblast papillae on the sheep conceptus at implantation. J. Anat. 134 (Pt 3):507-516.

Wurst, A. K. 2007. Effects of ovulation of aged follicles, pregnancy diagnosis by ultrasonography, and treatments during lactation on reproduction in ewes. Dissertation. West Virginia University.

Wurst, A.K., A.B. Dixon, and E.K. Inskeep. 2007. Lack of effect of transrectal ultrasonography with restraint on lambing rate and prolificacy in ewes. Theriogenology 68:1012-1016.

Yakubu, D. P., A. Mostyn, V. Wilson, S. Pearce, M. C. Alves-Guerra, C. Pecqueur, B. Miroux, H. Budge, T. Stephenson, and M. E. Symonds. 2007. Different effects of maternal parity, cold exposure and nutrient restriction in late pregnancy on the abundance of mitochondrial proteins in the kidney, liver and lung of postnatal sheep. Reproduction 133: 1241 - 1252.

Zarrouk, A., I. Engeland, J. Sulon, and J.F. Beckers. 1999a. Determination of pregnancyassociated glycoprotein concentrations in goats (capra hircus) with unsuccessful pregnancies: a retrospective study. Theriogenology 51:1321-1331.

Zarrouk, A., I.V. Engeland, J. Sulon, and J.F. Beckers. 1999b. Pregnancy-associated glycoprotein levels in pregnant goats inoculated with bartoxoplasma gondii or barlisteria monocytogenes : a retrospective study. Theriogenology 52:1095-1104. 
Name: $\quad$ Tammy L. Holler

Parents: $\quad$ Thomas C. Holler \& Neomia A. Holler

Date of Birth: 1972

Place of Birth: Oakland, Maryland

Schools Attended:

Garrett College 2004

McHenry, Maryland

Associate in Applied Science Agriculture Management

University of Maryland 2004

College Park, MD

2-yr Certificate Agriculture Business Management

West Virginia University 2006

Morgantown, WV.

B.S. in Animal \& Veterinary Science 